\title{
əComparing Evapotranspiration from Eddy Covariance Measurements, Water Budgets, Remote Sensing, and Land Surface Models over Canada ${ }^{a, b}$
}

\author{
Shusen Wang, ${ }^{\mathrm{c}}$ Ming Pan, ${ }^{\mathrm{d}}$ QiaOzhen Mu, ${ }^{\mathrm{e}, \mathrm{f}}$ XiaOying Shi, ${ }^{\mathrm{g}}$ JiAfu MaO, ${ }^{\mathrm{g}}$ Christian BrüMmer,

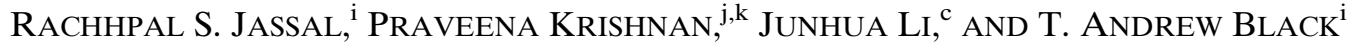 \\ ${ }^{\mathrm{c}}$ Canada Centre for Mapping and Earth Observation, Natural Resources Canada, Ottawa, Ontario, Canada \\ ${ }^{\mathrm{d}}$ Department of Civil and Environmental Engineering, Princeton University, Princeton, New Jersey \\ ${ }^{\mathrm{e}}$ College of Forestry and Conservation, University of Montana, Missoula, Montana \\ ${ }^{\mathrm{f}}$ Department of Geographical Sciences, University of Maryland, College Park, College Park, Maryland \\ ${ }^{\mathrm{g}}$ Environmental Sciences Division, and Climate Change Science Institute, Oak Ridge National Laboratory, Oak Ridge, Tennessee \\ ${ }^{\mathrm{h}}$ Thünen Institute of Climate-Smart Agriculture, Braunschweig, Germany \\ ${ }^{\mathrm{i}}$ Biometeorology and Soil Physics Group, The University of British Columbia, Vancouver, British Columbia, Canada \\ ${ }^{\mathrm{j}}$ Atmospheric Turbulence and Diffusion Division, NOAA, Oak Ridge, Tennessee \\ ${ }^{\mathrm{k}}$ Oak Ridge Associated Universities, Oak Ridge, Tennessee
}

(Manuscript received 3 October 2014, in final form 26 January 2015)

\begin{abstract}
This study compares six evapotranspiration ET products for Canada's landmass, namely, eddy covariance EC measurements; surface water budget ET; remote sensing ET from MODIS; and land surface model (LSM) ET from the Community Land Model (CLM), the Ecological Assimilation of Land and Climate Observations (EALCO) model, and the Variable Infiltration Capacity model (VIC). The ET climatology over the Canadian landmass is characterized and the advantages and limitations of the datasets are discussed. The EC measurements have limited spatial coverage, making it difficult for model validations at the national scale. Water budget ET has the largest uncertainty because of data quality issues with precipitation in mountainous regions and in the north. MODIS ET shows relatively large uncertainty in cold seasons and sparsely vegetated regions. The LSM products cover the entire landmass and exhibit small differences in ET among them. Annual ET from the LSMs ranges from small negative values to over $600 \mathrm{~mm}$ across the landmass, with a countrywide average of $256 \pm 15 \mathrm{~mm}$. Seasonally, the countrywide average monthly ET varies from a low of about $3 \mathrm{~mm}$ in four winter months (NovemberFebruary) to $67 \pm 7 \mathrm{~mm}$ in July. The ET uncertainty is scale dependent. Larger regions tend to have smaller uncertainties because of the offset of positive and negative biases within the region. More observation networks and better quality controls are critical to improving ET estimates. Future techniques should also consider a hybrid approach that integrates strengths of the various ET products to help reduce uncertainties in ET estimation.
\end{abstract}

\section{Introduction}

Evapotranspiration ET is the water lost from the land surfaces to the atmosphere through soil and water

๖ Denotes Open Access content.

\footnotetext{
${ }^{\text {a }}$ Supplemental information related to this paper is available at the Journals Online website: http://dx.doi.org/10.1175/JHM-D-14-0189.s1.

${ }^{\mathrm{b}}$ Earth Science Sector Contribution Number 20140252.

Corresponding author address: Shusen Wang, Canada Centre for Mapping and Earth Observation, National Resources Canada, 560 Rochester St., Ottawa ON K1A 0E4, Canada.

E-mail: shusen.wang@nrcan.gc.ca
}

surface evaporation and plant transpiration. ET is an important component in both the land surface energy balance and water budget and thus plays a critical role in the weather/climate system and the hydrological cycle. The magnitude and timing of ET can strongly affect the atmosphere, surface and subsurface processes such as cloud development (Molders and Raabe 1996), the ecosystem carbon and nitrogen cycles (Wang et al. 2002a; Zaehle et al. 2014; De Kauwe et al. 2014), surface albedo and temperature (Wang and Davidson 2007; Xiong and Qiu 2014), river discharge (Koster and Milly 1997), and groundwater recharge (Renger et al. 2007; Githui et al. 2012). Accurate estimation of ET is critical to climate/weather modeling, ecosystem and environmental assessment, and water resources management. 
ET is controlled by atmospheric demand (potential ET) and surface water availability, which are in turn influenced by climate, vegetation, and soil. Canada's landmass covers a land area of 9.1 million $\mathrm{km}^{2}$ with inland water bodies of almost 0.9 million $\mathrm{km}^{2}$, extending northward from $42^{\circ}$ to $83^{\circ} \mathrm{N}$. The climate, land cover, soil, and topography change dramatically across this large landmass and over time as well, which makes ET estimation highly complicated. On the other hand, the hydrometeorological observation networks are very sparse over the region (McKenney et al. 2006). For example, the number of hydrometric stations operated by the Water Survey of Canada has decreased to 2862 in 2008 since its peak of 3417 in 1984 (Mlynowski et al. 2011), and there are basically no consistent measurements of river discharge $Q$ for the latitudes above $70^{\circ} \mathrm{N}$. The measurement accuracies under winter freezing conditions for hydrometeorological variables such as precipitation $P$ and $Q$ could also deteriorate substantially. The complicated climate and surface conditions and the lack of accurate data pose significant challenges for estimating ET for the landmass.

Evapotranspiration can be estimated at various scales by different approaches. At the site scale, the eddy covariance EC technique has been commonly used. From regional to global scales, ET is often estimated indirectly using the surface water budget, remote sensing, or land surface models (LSMs). The advantages, limitations, and uncertainties of the ET products from these approaches vary with regional conditions and with spatial and temporal scales. In a recent study, Long et al. (2014) assessed the uncertainty in ET outputs from LSMs, remote sensing, and the surface water budget over three river basins in the south-central United States. They found that the uncertainties are lowest in LSMs, moderate in the remote sensing approach, and highest in the water budget approach. Their results also suggest that there is a trade-off between spatial resolution and uncertainty, with lower uncertainty in coarser-resolution ET estimates. In another study, S. Wang et al. (2013) compared ET estimates from available studies employing LSMs, atmospheric models, the atmosphere moisture budget, the surface water budget, remote sensing, and empirical methods for the Mackenzie River basin (MRB) and the Saskatchewan River basin in midwestern Canada. They found that ET varied significantly among these approaches. ET from atmospheric models showed the largest deviations from the median values, and ET from LSMs and surface water budget showed small uncertainties. This study has several limitations. First, it is based on basin-average ET, which makes it difficult for detailed data comparisons. Second, it is limited to two basins. The uncertainties in ET across the entire landmass are yet to be better quantified. Third, the study basins have very large drainage areas (e.g., the MRB has 1.8 million $\mathrm{km}^{2}$ ). ET varies substantially within such large basins, and the study did not evaluate spatial variability. Moreover, uncertainty in ET estimates tends to be scale dependent, and the basin results may not apply at the subbasin scales.

The first objective of this study is to compare six ET datasets over Canada created from EC measurements, surface water budgets, remote sensing, and LSMs. Specifically, the first dataset was assembled from 14 fluxtower sites where ET has been measured using the EC technique. The second dataset was inferred from the surface water budget for all the available watersheds in Canada. The third dataset was derived from the Moderate Resolution Imaging Spectroradiometer (MODIS) satellite observation. The other three datasets were the outcome of three different LSMs, including the Community Land Model (CLM), the Ecological Assimilation of Land and Climate Observations (EALCO) model, and the Variable Infiltration Capacity model (VIC). The second objective is to characterize the ET climatology over this vast landmass and discuss the advantages, limitations, uncertainties, and error sources for each dataset. We will also compare ET at different spatial scales, including watersheds and ecozones, as well as the national summaries. The analysis will provide water resources managers with improved ET information and help researchers better understand the ET processes in a variety of cold region ecosystems that contribute to the improvement of weather/climate modeling. The analysis also intends to provide important information for further improving hydrometeorological observation networks and data quality controls. The comparisons at different spatial scales will help understand the scale dependence of ET uncertainties, which is important in comparing results from different studies.

\section{Methods and datasets}

\section{a. ET from EC measurement}

This dataset of ET measured at 14 sites using the EC technique was assembled from the studies of Brümmer et al. (2012), Krishnan et al. (2006), and Jassal et al. (2009). The sites were the major sites of the Fluxnet-Canada Research Network (FCRN) and the Canadian Carbon Program (http://fluxnet.ornl.gov/site_list/Network/3). Brief information about the sites is given in Table 1 . The land-cover types of the sites include forest (11 sites), peatland (2 sites), and grassland (1 site). The sites stretch across southern Canada up to $56^{\circ} \mathrm{N}$ in a coast-to-coast continental-scale transect from British Columbia to New Brunswick (Fig. 1). These sites were 
TABLE 1. Comparison of annual ET values at the 14 flux-tower sites from EC measurements, remote sensing MOD16, and the LSMs of CLM, EALCO, and VIC. The ET from MOD16 and the LSMs is calculated for the same time period of EC measurements, except that MOD16 does not include years before 2000 for the BC-DF49 and SK-OA sites. CLM has no data for the pixel where BC-HDF88 is located because of its coarse resolution. All the statistics are based on average ET for each station for the specified time period. Note that Saskatchewan Old Aspen does not include year 1995.

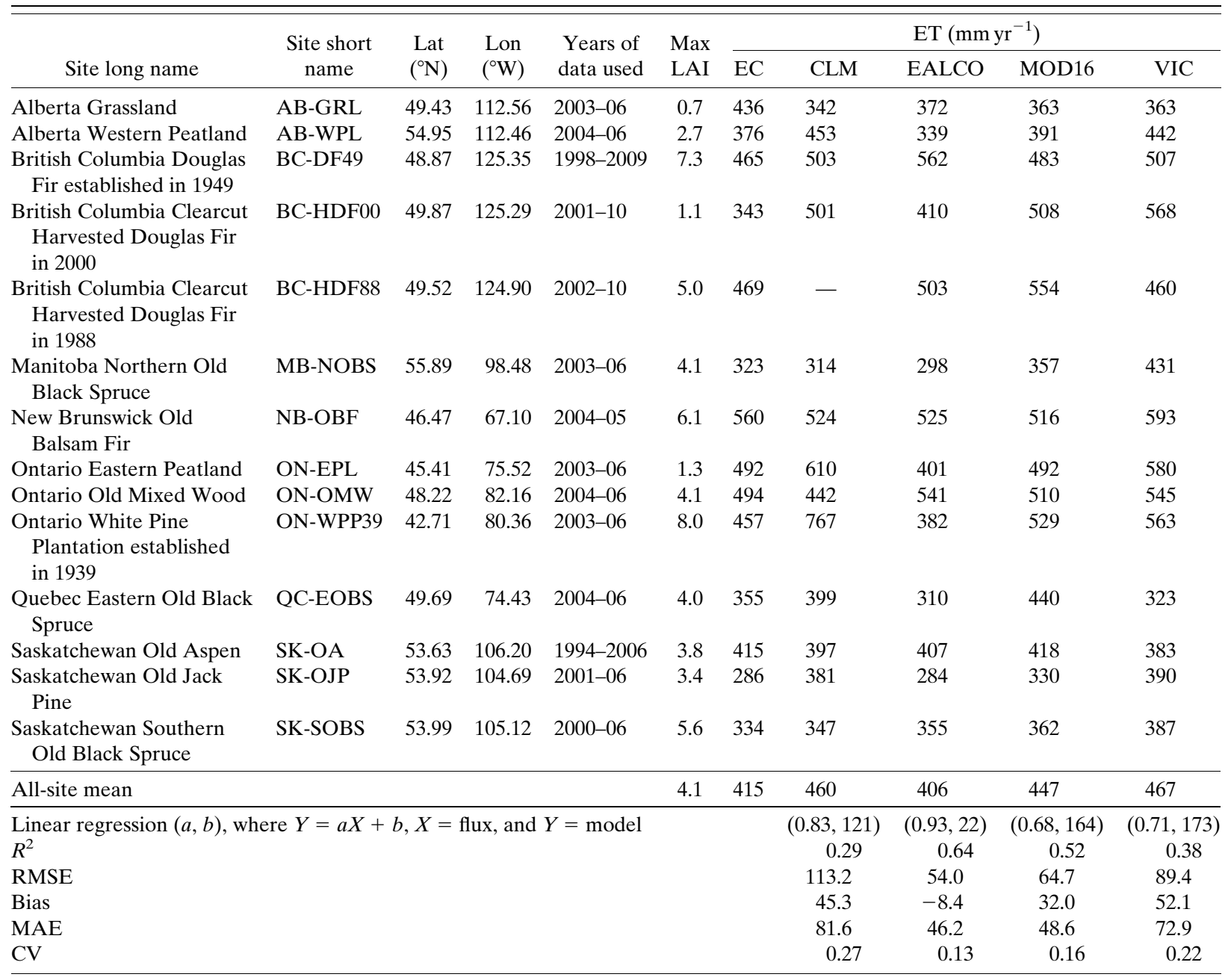

located across the major ecozones in southern Canada, which include the Pacific Maritime, Boreal Plain, Boreal Shield, Prairie, Mixed Wood Plain, and Atlantic Maritime (Fig. 1). Monthly and annual datasets of ET were obtained from the quality-controlled and gap-filled halfhourly estimates of ET over the sites. The values of ET used in this study were corrected for energy-balance closure by preserving the measured Bowen ratio (Twine et al. 2000). The closure varied mostly between 0.85 and 0.90 among the sites based on multiyear observations. Further details on the experimental setup, calibration, EC flux measurements, data processing, and quality-control methods, including data filtering for low-turbulence periods and the details on the data gap-filling methods, can be found in the above references.

\section{b. ET from surface water budget}

All the watersheds in Canada that have $Q$ data available during the 30-yr period of 1981-2010 were identified based on the Atlas of Canada watersheds database (http:// geogratis.gc.ca). This includes a total of 370 watersheds (Table S1 in the supplemental material) covering a total area of 3.9 million $\mathrm{km}^{2}$, or $39 \%$ of the entire Canadian landmass (land plus inland water). Spatially, it provides a fairly good coverage for the country except for the $\mathrm{Ca}$ nadian Arctic archipelago (Fig. 1). The watersheds are distributed over 14 of the 15 ecozones of the country except the Arctic Cordillera. Area $A$ of the watersheds ranges from 170 to $146400 \mathrm{~km}^{2}$. About $10 \%$ of the watersheds are $<600 \mathrm{~km}^{2}$ and about $10 \%$ are $>30000 \mathrm{~km}^{2}$. 


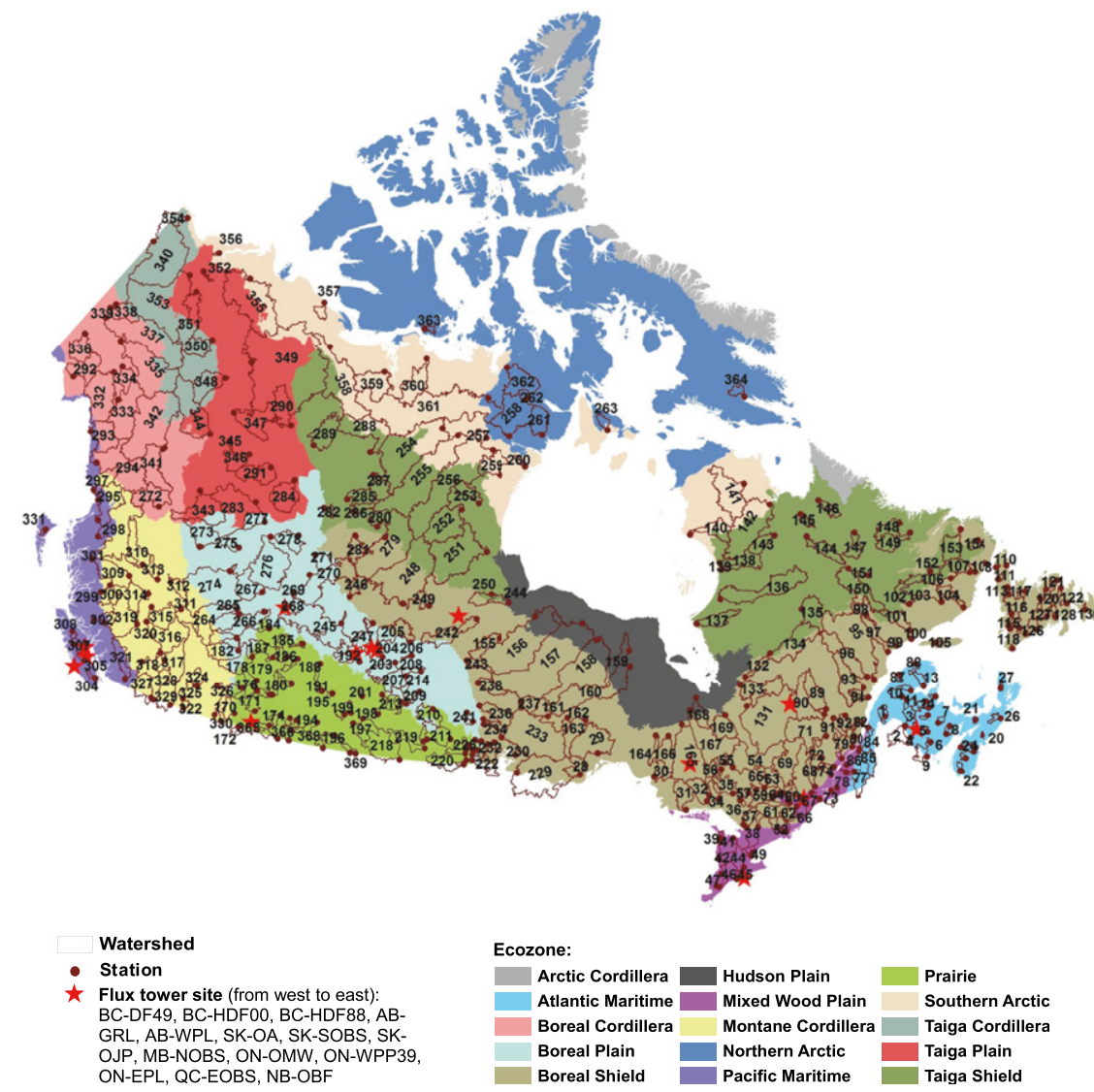

FIG. 1. Geographic locations of the 14 flux-tower measurement sites, the 370 watersheds and their corresponding hydrometric stations (see details by watershed numbers in Table S1), and the 15 terrestrial ecozones for Canada's landmass.

The median watershed size is about $3960 \mathrm{~km}^{2}$. Most of the large watersheds are found in the mid- to high latitudes.

At multiyear or longer time scales, the net change of water storage for a watershed is negligible when compared with the total values of $P, \mathrm{ET}$, and $Q$. As such, the longterm average ET for a watershed can be estimated as ET $=$ $P-Q$. The $Q$ data $\left(\mathrm{m}^{3} \mathrm{~s}^{-1}\right)$ as well as values of $A$ for the watersheds were from the Water Survey of Canada (www. ec.gc.ca/rhc-wsc/). Values of $Q$ were then converted to water depth (mm) by dividing by respective values of $A$. For the 30-yr study period, the average length of the data record was 20.8 years; $47 \%$ of the watersheds had $>25$ years of records and only $6 \%$ had $<5$ years of records. The median record length was 22 years (Table S1).

The precipitation values for the watersheds were calculated using the monthly gridded data from McKenney et al. (2011), which have 150 -arc-s $(\sim 5 \mathrm{~km})$ resolution and provide full coverage of North America for the period of 1901-2010. It was produced by interpolating climate station measurements using thin-plate smoothing splines. A trivariate spline model, incorporating the effects of latitude and longitude as well as a spatially and temporally varying elevation effect, was used. The data are from weather station measurements made by the Meteorological Service of Canada (MSC) and underwent MSC quality controls to remove obvious data errors. No attempt was made to adjust the data for potential biases such as the wind-induced undercatch of snow.

The water budget ET was calculated for the years with $P$ and $Q$ data available for each watershed (Table S1). The errors in the $Q$ and $P$ datasets vary substantially in time and space over Canada's landmass (Wang et al. 2014b), and they are the main sources of uncertainties in the ET estimates from the surface water budget approach. As one of the objectives of this study, the errors in $Q$ and $P$ were assessed through evaluating the water budget ET and discussed in detail in section 4 .

Most of the watersheds contain substantial areas of water surfaces (e.g., lakes and rivers). The mean percentage of water surface for the 370 watersheds is $11 \%$ (Table S1). ET from the water budget approach is thus a combination of land surface ET and water surface evaporation $E_{0}$ within a watershed. On the other hand, ET from other datasets refers to land surface only. The 
effect of $E_{0}$ in the comparisons between the water budget ET and other datasets was accounted for and described later [in section $2 \mathrm{~d}(3)$ ].

\section{c. Remote sensing ET from MODIS: MOD16}

The MOD16 retrieval algorithm $(\mathrm{Mu}$ et al. 2007a, 2011) is based on the Penman-Monteith framework with modifications to account for parameters not readily available from space (Cleugh et al. 2007). The algorithm accounts for both surface energy partitioning and environmental constraints on ET and includes canopy transpiration, canopy evaporation, and soil evaporation. Atmospheric relative humidity $\mathrm{RH}$ is used to estimate the proportion of wet soil and wet canopy components (Fisher et al. 2008). The proportion of vegetation cover is derived from the fractional absorbed photosynthetically active radiation FPAR (Los et al. 2000) and is used to partition net radiation between vegetation and soil surfaces. Leaf stomatal conductance is determined by the mean daytime vapor pressure deficit VPD and daily minimum air temperature and further upscaled to dry canopy conditions using the leaf area index LAI. Soil evaporation is estimated as the potential evaporation rate for wet soil surfaces and scaled down by $\mathrm{RH}$ for moist soil conditions (Fisher et al. 2008). MOD16 has been widely validated and used in regional and global analyses (e.g., Montenegro et al. 2009; Jung et al. 2010; Loarie et al. 2011; Lathuillière et al. 2012).

The input data include MODIS global $1-\mathrm{km}^{2}$ collection 4 land-cover type 2 (MOD12Q1; Friedl et al. 2002), collection 5 FPAR/LAI (MOD15A2; Myneni et al. 2002), collection 5 albedo (the 10th band of the whitesky albedo from MCD43B2/3; Salomon et al. 2006; Schaaf et al. 2002), and global MERRA GMAO meteorological data at $\sim 0.5^{\circ} \times 0.6^{\circ}$ resolution. MOD16 at 1 $\mathrm{km}$ resolution for the years $2000-10$ is used in this study. During this time period, 134 watersheds have no $Q$ data available for comparisons. Furthermore, ET is not calculated for 1) barren or sparsely vegetated land, 2) permanent snow and ice, 3) permanent wetland, 4) urban or built-up areas, and 5) other unclassified pixels, which results in $25.5 \%$ of the landmass having no data. Data gaps primarily occur for the Arctic, which prevents the countrywide estimates. Fortunately, the gaps have less impact on the watershed ET comparisons as there are also no study watersheds in the Arctic. There are 11 (or 3\%) watersheds that have data gaps $>30 \%$ (Fig. 2). These watersheds are mostly in the far north. There are 75 (or $20 \%$ ) watersheds that have data gaps $>10 \%$. These data gaps may lead to biases in the watershed or ecozone ET averaged from available pixels. This will be noted in the later comparisons.

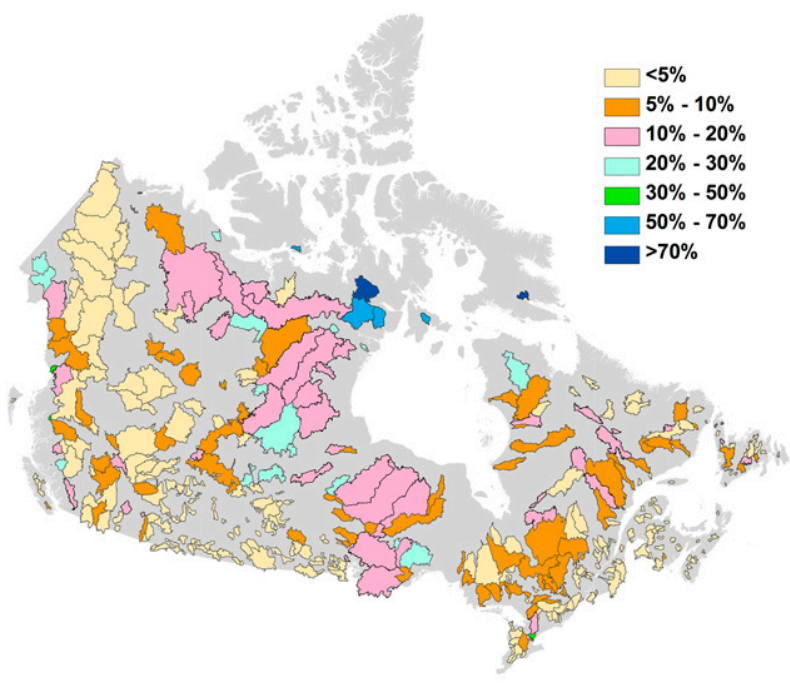

FIG. 2. MOD16 data gaps over the 370 watersheds. The gray background indicates the nonstudied areas of Canada's landmass.

\section{d. ET from LSMs}

\section{1) CLM}

CLM with carbon $(\mathrm{C})$ and nitrogen $(\mathrm{N})$ biogeochemical components (CLMCN) is used (Thornton and Zimmermann 2007; Oleson et al. 2010) in this study. This model is prognostic in terms of the dynamic simulation of plant phenology, the transfer of energy, and the hydrologic cycle in the vegetation-soil system. It separates the canopy into sunlit and shaded leaves. Significant changes in improving the simulated hydrological cycle include the updating of surface vegetation datasets and the modification of canopy and soil hydrology parameterizations (Oleson et al. 2008). Based on model outputs and the limited observational data, the global partitioning of CLM ET into canopy transpiration, evaporation, and soil evaporation was adjusted (Lawrence et al. 2007). This leads to significant increases in transpiration and photosynthesis, and larger interseasonal changes in soil water storage.

For this study, the global offline mode of CLM at $0.5^{\circ} \times$ $0.5^{\circ}$ spatial resolution and 30-min time step is driven by the historical CRUNCEP data (a hybrid dataset based on CRU time series and NCEP-DOE AMIP-II reanalysis; http:// dods.extra.cea.fr/store/p529viov/cruncep; Viovy 2011), the soil data (Global Soil Data Task 2000), and the dynamic land-use and land-cover change (Hurtt et al. 2006) to obtain estimates of ET over the landmass of Canada for 1981-2009. More details about the setup, evaluation, and application of this version of CLM with the standard CRUNCEP dataset can be found in Mao et al. (2012, 2013), Shi et al. (2013), and K. Wang et al. (2013). 


\section{2) EALCO}

EALCO simulates land surface radiation transfer (Wang 2005; Wang et al. 2007), energy balance (Wang et al. 2002a, 2009; Zhang et al. 2008), water transfer (Wang 2008), and $\mathrm{C}$ and $\mathrm{N}$ biogeochemical cycles (Wang et al. 2001, 2002b) at a 30-min time step. ET is obtained by simulating canopy transpiration, canopy evaporation/sublimation of intercepted rain/snow, soil/ snow evaporation/sublimation, and evaporation of water from temporary puddles after rain events. EALCO simulates plant phenology and separates the canopy into sunlit and shaded leaves. The model has been calibrated and validated in a number of independent studies as reported in Hanson et al. (2004), Grant et al. (2005, 2006), Fernandes et al. (2007), Mi et al. (2009), Widlowski et al. (2011), De Kauwe et al. (2013), and Zaehle et al. (2014).

ET was produced at $5-\mathrm{km}$ resolution for the period of 1981-2010 using land-cover and canopy LAI datasets from remote sensing (S. Wang et al. 2013), soil data from the Soil Landscapes of Canada database (Agriculture and Agri-Food Canada 1996), and atmospheric forcing (Sheffield et al. 2006). The latter was originally at $1.0^{\circ}$ spatial and 3-h temporal resolutions and was downscaled to $10 \mathrm{~km} \times 10 \mathrm{~km}$ grids using bilinear interpolation and to 30-min time steps using the method developed in Global Soil Wetness Project (www.iges.org/gswp2/ util/drv_finterp.f90). No subpixel downscaling of the atmospheric forcing was applied.

\section{3) VIC}

VIC (Liang et al. 1994, 1996) works at a pixel scale (from a few to hundreds of kilometers) to resolve both the moisture and energy exchanges between the land surface and atmosphere. The key process, partitioning of rainfall into infiltration and surface runoff, is based on the concept of statistically distributed soil water holding capacity (Wood et al. 1992). VIC treats the canopy as one layer and ET is calculated using the PenmanMonteith equation (Monteith and Unsworth 1990). A number of techniques are used to address the subgrid variability, for example, fractional storm area and precipitation redistribution within a grid (Liang et al. 1996), internal temporal downscaling, subpixel vegetation tiles and elevation bands, and subpixel forcing adjustment for elevation effects (Liang et al. 1994). VIC has been implemented, calibrated, and validated in a large number of applications at regional, continental (Mitchell et al. 2004), and global (Sheffield and Wood 2007) scales.

The VIC simulation used in this study is carried out as part of the NASA Making Earth System Data Records for Use in Research Environments (MEaSUREs) program (M. Pan et al. 2015, unpublished manuscript) to provide global estimates of water cycle variables (Pan et al. 2012). The simulation is performed at $0.25^{\circ}$ resolution at a 3-hourly time step for the period 19482010 , forced by an enhanced version of Sheffield et al. (2006) data. The land-cover, LAI, and soil datasets are based on the global 1-km University of Maryland dataset (Hansen et al. 2000), the Advanced Very High Resolution Radiometer (AVHRR) satellite data (Gutman and Ignatov 1998), and the State Soil Geographic (STATSGO) database (Miller and White 1998), respectively.

ET from MODIS and the LSMs refers to the land surface, but ET from the surface water budget includes both ET from land surface and $E_{0}$ from water surface within a watershed. To make them comparable, watershed-level water loss to the atmosphere $\mathrm{ET}_{\text {composite }}$ from MODIS and LSMs products is calculated as

$$
\mathrm{ET}_{\text {composite }}=\frac{1}{N} \sum_{n=1}^{N}\left[\left(1.0-\alpha_{n}\right) \mathrm{ET}_{n}+\alpha_{n} E_{0 n}\right],
$$

where $\mathrm{ET}_{n}, E_{0 n}$, and $\alpha_{n}$ are the $\mathrm{ET}, E_{0}$, and the fraction of water surface for pixel $n$, and $N$ is the total number of pixels in a watershed. To calculate $E_{0}$, the Penman equation implemented in EALCO is used. The parameter $\alpha$ is calculated from the Water Fraction Coverage Map of Canada (Pavlic et al. 2002). Ecozone ET is calculated as the area-weighted average of the ET for all the watersheds within each ecozone.

\section{Results}

In this section, intercomparisons of the ET products from MODIS and the LSMs are first discussed. Their ET values at the pixels containing the $14 \mathrm{EC}$ sites and in the years corresponding to the EC observations are then extracted and compared with the EC measurements, followed by the comparisons with the water budget ET at watershed scale using the years with data available for the compared data products.

\section{a. Intercomparison of ET from MODIS and the LSMs}

\section{1) Mean annual ET}

The mean annual ET values from MODIS and the LSMs demonstrated similar spatial patterns (Fig. 3a). The high values were fairly similar and mostly distributed in the southeastern part of the landmass, including the Mixed Wood Plains and Atlantic Maritime ecozones. Some regions in the southwest part also showed 
(a)
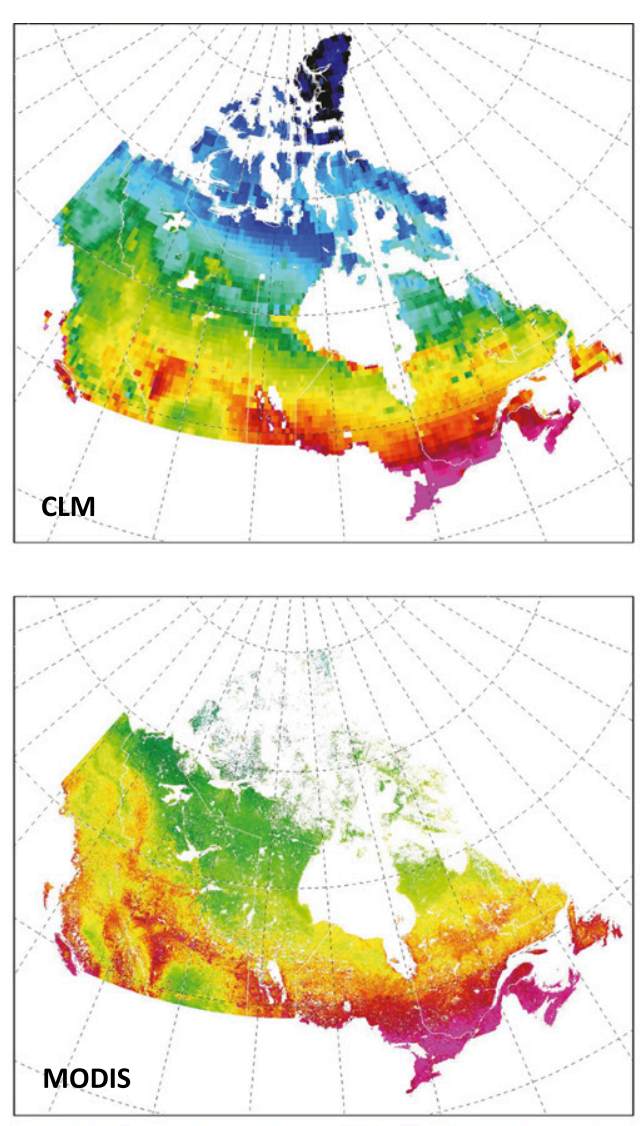

0

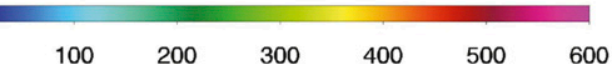

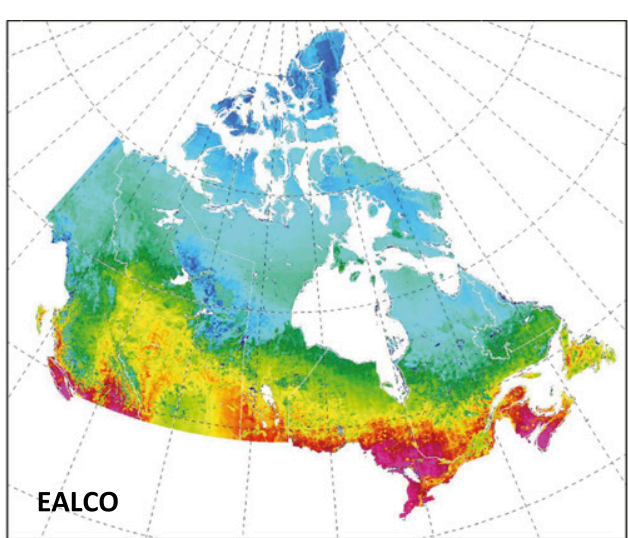
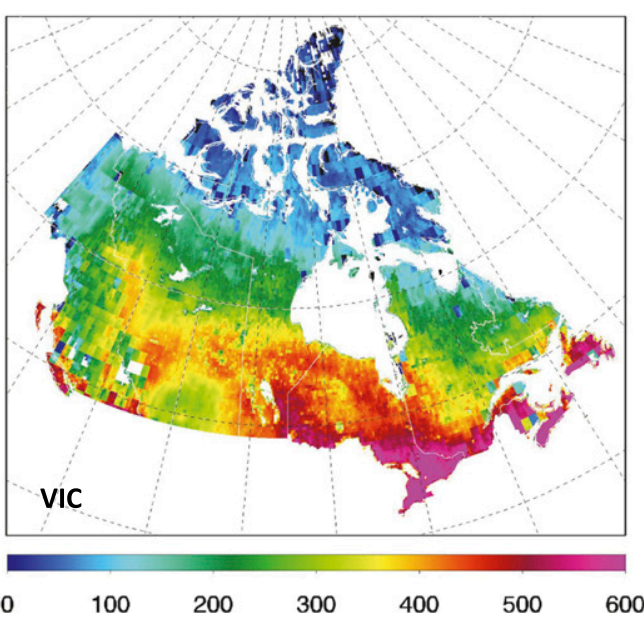

FIG. 3. (a) Mean annual ET ( $\left.\mathrm{mm} \mathrm{yr}^{-1}\right)$ from CLM, EALCO, MOD16, and VIC. Negative values are in black. MOD16 has $25.5 \%$ of the area with no data, primarily in the Arctic. (b) Histogram of mean annual ET (10 $\mathrm{mm} \mathrm{yr}^{-1}$ bins) from CLM, EALCO, MOD16, and VIC. Note that MOD16 dataset has large gaps over the north, as shown in (a).

high values. The maximum and top one percentile mean annual ET by CLM, EALCO, MOD16, and VIC were 868 and 590, 828 and 550, 811 and 590, and 726 and $620 \mathrm{~mm} \mathrm{yr}^{-1}$, respectively (Fig. 3b). The high ET was the result of several processes. First, these regions had relatively high solar irradiance and air temperature, which typically reach $4500 \mathrm{MJ} \mathrm{m}^{-2} \mathrm{yr}^{-1}$ and $5^{\circ}-10^{\circ} \mathrm{C}$ (annual mean), respectively. The $P$ over these regions was also high, ranging from 600 to above $1000 \mathrm{~mm} \mathrm{yr}^{-1}$. Second, vegetation in these regions was dominated by dense forests and agricultural crops, providing high hydraulic conductance for plant water uptake and transpiration in the growing season. Third, the above land-cover types exhibited low surface albedo that contributed to the high absorption of solar radiation.

The above four ET products showed lower values $\left(<300 \mathrm{~mm} \mathrm{yr}^{-1}\right)$ in the southern Canadian Prairies and the Western Cordillera (Fig. 3a) than the surrounding regions. The southern Canadian Prairies had the highest potential ET of about $1000 \mathrm{~mm} \mathrm{yr}^{-1}$ in the country, but it had low $P\left(<300-400 \mathrm{~mm} \mathrm{yr}^{-1}\right)$ due to the rain-shadow effect of the Western Cordillera. The much lower $P$ than the potential ET often leads to severe plant water stress in summer. The region is dominated by grassland with low LAIs of mostly $<1-2 \mathrm{~m}^{2} \mathrm{~m}^{-2}$, which also contributed to the low ET. The low ET in the Western Cordillera region was mainly a result of low temperature and vegetation cover. Some areas in the valleys also had water limitations because of the rain-shadow effect.

All the ET products exhibited a large decrease with latitude (Fig. 3a), a result of the northward decrease in solar irradiance and air temperature. The annual surface solar irradiance in the high Arctic was about $2500 \mathrm{MJ} \mathrm{m}^{-2} \mathrm{yr}^{-1}$, less than $60 \%$ of that in the south. The mean annual air temperature was $<-15^{\circ} \mathrm{C}$. As expected, all the products showed the lowest ET in the high Arctic. However, the low values obtained by different products differed substantially (Fig. 3b). The 


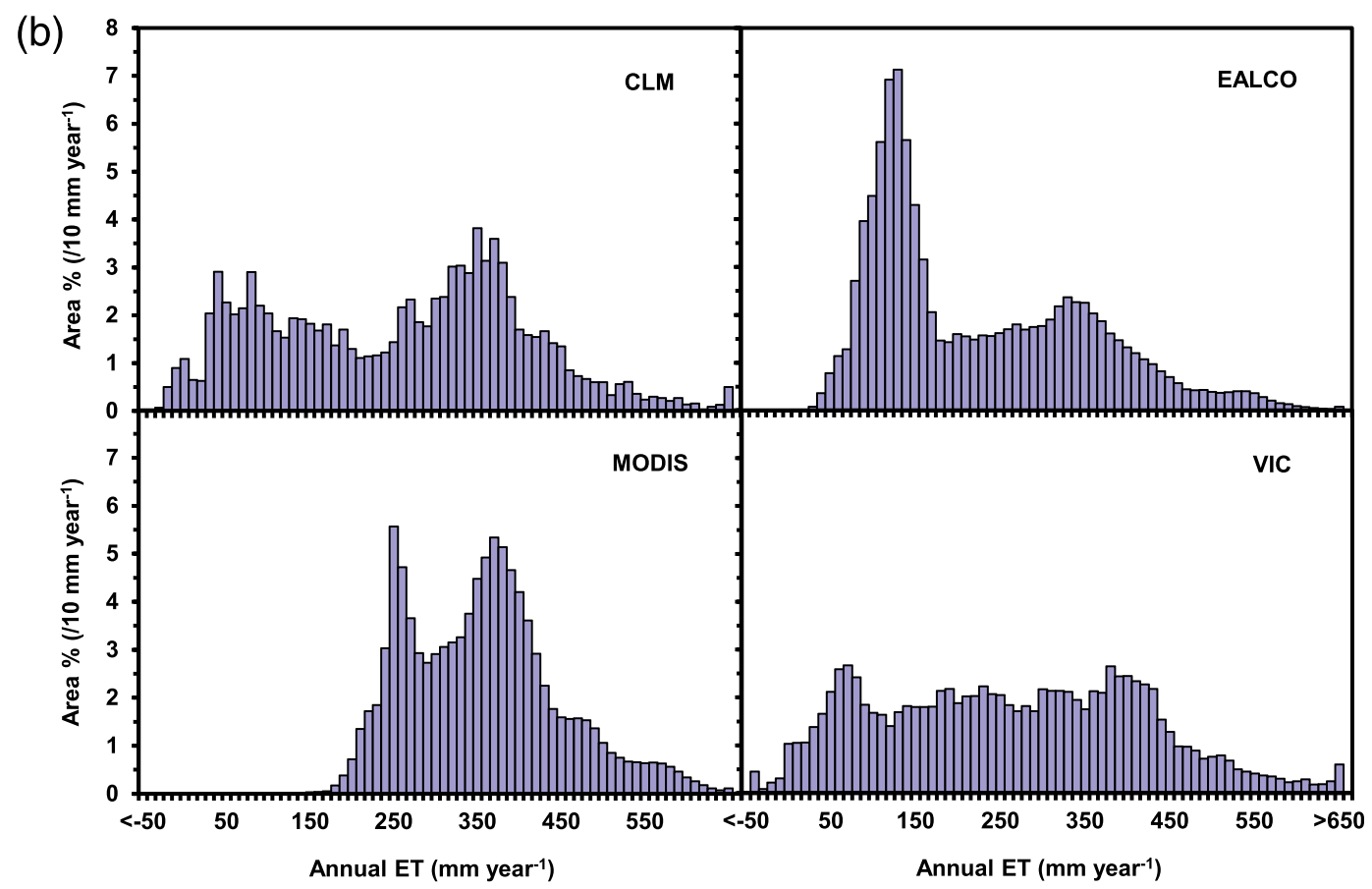

FIG. 3. (Continued)

minimum and bottom one percentile mean annual ET by CLM, EALCO, MOD16, and VIC were -40 and $-10,-18$ and 50, 130 and 200, and -307 and $0 \mathrm{~mm} \mathrm{yr}^{-1}$, respectively. The negative values from CLM, EALCO, and VIC indicated a net annual water condensation (dew and frost). The less negative values from EALCO were partially due to the screening of oversaturated air in the atmospheric forcing. The MOD16 algorithm did not include the water vapor condensation process, so it had no negative values.

The four products showed the largest differences in the mid- to high latitudes. MOD16 was substantially higher than that from the LSMs over these regions. Together with the data gaps in the Arctic, MOD16 had few areas with ET $<150 \mathrm{~mm} \mathrm{yr}^{-1}$ and relatively large areas in the range of $250-400 \mathrm{~mm} \mathrm{yr}^{-1}$ (Fig. 3b). The high ET from MOD16 was largely due to its high values in winter, as discussed below. In MOD16 ET algorithm, VPD is the only variable representing water stress; it is difficult to fully capture the environmental water stress both from atmosphere and soil moisture (Mu et al. 2007b). In addition, VPD is derived from the coarseresolution MERRA meteorology data, which cannot reflect the water stress over small-scale regions such as the irrigated croplands. Long et al. (2014) found lower MOD16 ET than the other ET datasets examined in the arid regions of the south-central United States, which is likely due to the overestimatation of VPD controls in ET in arid regions (Mu et al. 2007b). In contrast,
EALCO had relatively low ET in the central part (e.g., Taiga Shield; Fig. 1). The low ET in this region was related to the vegetation datasets used by EALCO, which had sparse or disturbed vegetation with most LAI < $1.0 \mathrm{~m}^{2} \mathrm{~m}^{-2}$. As a result, EALCO had relatively large areas with ET in the range of $100-150 \mathrm{~mm} \mathrm{yr}^{-1}$ (Fig. 3b).

The nationwide mean annual ET values from the three LSMs were fairly similar, which were 261,239, and $267 \mathrm{~mm} \mathrm{yr}^{-1}$ for CLM, EALCO, and VIC, respectively. The MOD16 dataset had gaps too large over the north to have an estimate for the national mean. For the rest of the landmass (i.e., the vegetated part), MOD16 gave a mean annual ET of $361 \mathrm{~mm} \mathrm{yr}^{-1}$. The corresponding ET values for this area by CLM, EALCO, and VIC were 278,251 , and $287 \mathrm{~mm} \mathrm{yr}^{-1}$, respectively.

\section{2) MeAn monthly ET}

The LSMs showed very low ET in winter across the landmass (Fig. 4a), as a result of low solar irradiance, which varied from $120 \mathrm{MJ} \mathrm{m}^{-2}$ month $^{-1}$ in the southeast to $0 \mathrm{MJ} \mathrm{m}^{-2}$ month $^{-1}$ in the Arctic in December, and low temperature, which varied from above $0^{\circ} \mathrm{C}$ on Vancouver Island to as low as $-30^{\circ} \mathrm{C}$ in the far north in January (monthly mean). ET in winter was dominated by snow sublimation and soil evaporation, as transpiration was mostly shut down because of the dormant (forests) or absent (agriculture and grassland) vegetation. Snow covered a large part of the landmass and its high albedo further contributed to the low ET. Regions 
(a)
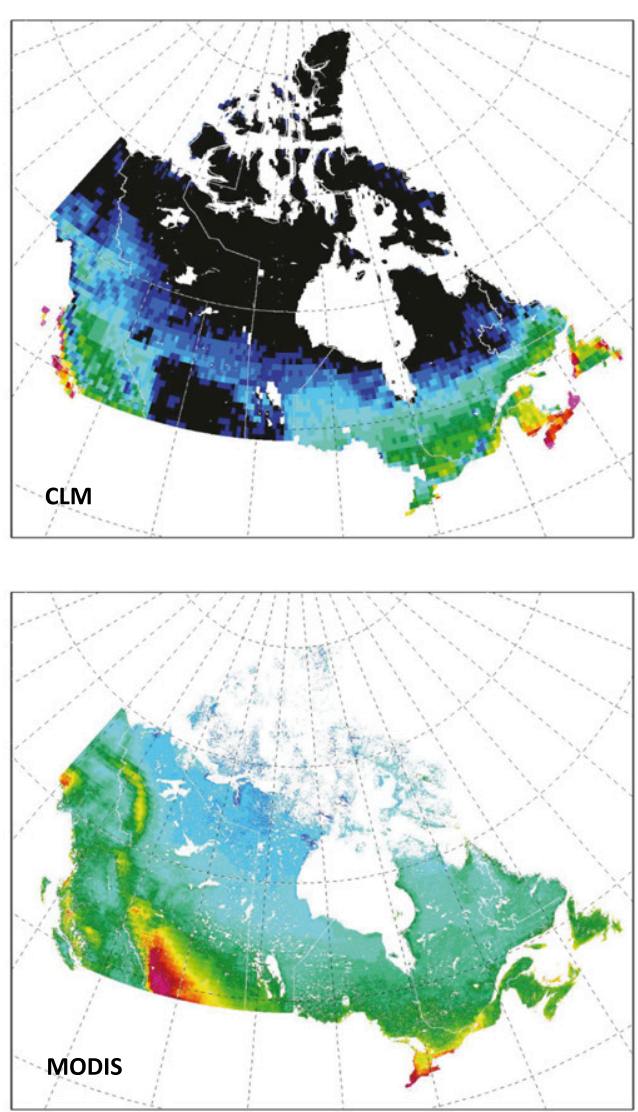

0

6 12 18

240
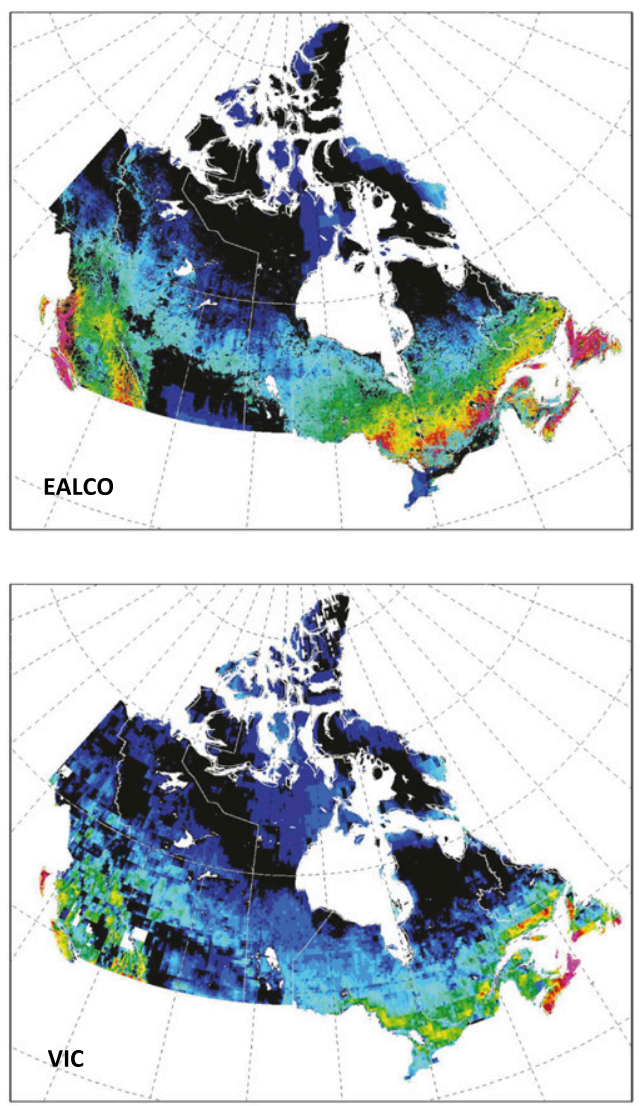

12

18

24

FIG. 4. (a) Mean monthly ET (mm month ${ }^{-1}$ ) from CLM, EALCO, MOD16, and VIC in December. Negative values are in black. (b) Histogram of the mean monthly ET ( $2 \mathrm{~mm} \mathrm{month}^{-1}$ bins) from CLM, EALCO, MOD16, and VIC in December.

with relatively high ET were found in the coastal regions where temperature was relatively high. The LSMs had negative ET in the Arctic, where the surface net radiation became negative after the polar night started. Negative ET was also found over regions in the south with little vegetation cover in winter, such as the Canadian Prairies. It is interesting to note that all three LSMs indicated higher ET over the vast boreal forest region than the Canadian Prairies to its south, although the forest region had less favorable climate conditions for ET. This is mainly due to the fact that the forest region had lower surface albedo than the snow-covered bare ground in the Canadian Prairies (Wang et al. 2006), resulting in greater absorption of radiation and less chance for water vapor condensation. The snow interception and its sublimation by the forest canopy also contributed to higher ET. MOD16 showed relatively high ET across the landmass, partially because it did not calculate water vapor condensation, which was shown to be substantial by the LSMs. Also, MOD16 treats snow as bare soil surface, which makes the ET in winter less reliable. Overall, maximum ET in midwinter was mostly less than $20 \mathrm{~mm} \mathrm{month}^{-1}$ across the landmass. The histograms for the three LSM products showed that most areas of the landmass had ET around $0 \mathrm{~mm}^{\text {month }}{ }^{-1}$ (Fig. 4b), while MOD16 had higher values partially due to the data gaps in the Arctic.

The four ET products showed a rapid increase in ET during April-May across the landmass, especially in the south, a result of increasing radiation and temperature as well as plant green-up. The ET difference between the Canadian Prairies and the forest region in winter as mentioned above disappeared in spring, mainly because of the wet soil and lower albedo after snowmelt over the Canadian Prairies. The four ET products showed large spatial variations in ET across the landmass in midsummer (Fig. 5a), primarily due to the large spatial differences in temperature and vegetation coverage. Mean monthly temperature in July exceeded $20^{\circ} \mathrm{C}$ in the southeast, but it was still $<5^{\circ} \mathrm{C}$ in the north. Values of 


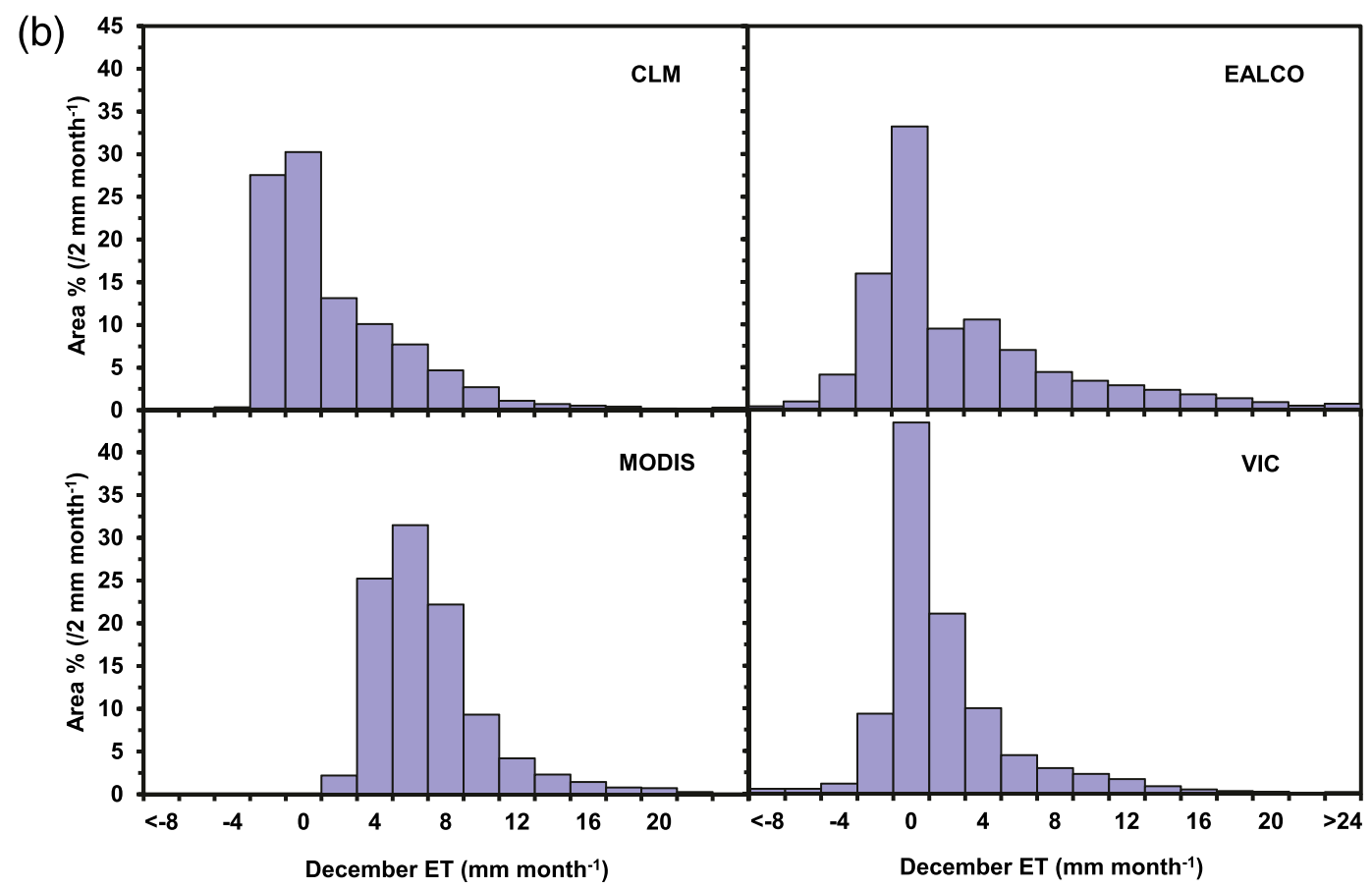

FIG. 4. (Continued)

LAI in the south could be over $5 \mathrm{~m}^{2} \mathrm{~m}^{-2}$ in July when plants were fully grown, but there was little vegetation coverage in the north. Monthly radiation values, however, were similar between the south and the north (about $600 \mathrm{MJ} \mathrm{m}^{-2}$ month $^{-1}$ in July) because of the complementary relationship between solar angle and day length. The EALCO ET in July was positive over the entire landmass, but CLM and VIC still produced negative ET values in some areas in the Arctic. The high ET values across the landmass in July were similar among the models, which were about $130 \mathrm{~mm}$ month $^{-1}$ (Fig. 5b).

The national averages of monthly ET agreed well among the three LSMs. During the four winter months of November-February, ET was as low as $2-4 \mathrm{~mm}$ month $^{-1}$ (Fig. 6). MOD16 produced relatively high ET values in midwinter because of the lack of data in the north and higher values in the south. ET peaked in July for all the models, with monthly totals of $65,61,76$, and $74 \mathrm{~mm} \mathrm{month}^{-1}$ for CLM, EALCO, MOD16, and VIC, respectively. The sum of ET in the three summer months of June-August accounted for a large proportion of the annual total, which was $63 \%$ on average for the four models.

\section{b. Comparison of MOD16 and LSMs ET with EC ET}

All the 14 EC sites are located in the south where ET is relatively high. The measured annual ET ranged from $286 \mathrm{~mm} \mathrm{yr}^{-1}$ at SK-OJP to $560 \mathrm{~mm} \mathrm{yr}^{-1}$ at NB-OBF (Table 1). The all-site mean was $415 \mathrm{~mm} \mathrm{yr}^{-1}$. As shown in Table 1, EALCO ET had the highest correlations with the EC measurements with a root-mean-square error RMSE of $54.0 \mathrm{~mm} \mathrm{yr}^{-1}$ and mean absolute error MAE of $46.2 \mathrm{~mm} \mathrm{yr}^{-1}$. The explained variance $R^{2}$ by the relationship was $64 \%(p<0.01)$ in EC ET, with a coefficient of variation $\mathrm{CV}$ of $13 \%$. EALCO also had a small bias of $-8.4 \mathrm{~mm} \mathrm{yr}^{-1}$, or $-2.0 \%$ of the measured ET. MOD16 also performed relatively well. It explained $52 \%(p<0.01)$ of the site variance with an RMSE of $64.7 \mathrm{~mm} \mathrm{yr}^{-1}$ and a CV of $16 \%$. Its MAE and bias were 48.6 and $32.0 \mathrm{~mm} \mathrm{yr}^{-1}$ (or $7.7 \%$ of the measured ET), respectively. CLM and VIC had relatively low agreements with the measurements, which is not surprising as the two models had coarser spatial resolutions $\left(0.5^{\circ}\right.$ and $0.25^{\circ}$, respectively) than those of EALCO and MOD16 (5 and $1 \mathrm{~km}$, respectively), resulting in a larger mismatch between their scales and the EC footprint, making the ET values less comparable.

Specifically for individual sites, SK-OA, the only deciduous forest site, had the best agreement between the modeled and measured annual ET (Table 1). The MAE of the four models was $3.7 \%$ of the measured ET. The models also performed relatively well at NB-OBF, ONOMW, SK-SOBS, BC-HDF88, and BC-DF49, of which the MAE by the four models were under $10 \%$ of the measured ET. On the other hand, all the models largely overestimated the ET at BC-HDF00. The MAE of the four models at this site was as high as $45 \%$ of the measured ET. This site represents a small area ( $\sim 30 \mathrm{ha})$ of 
(a)
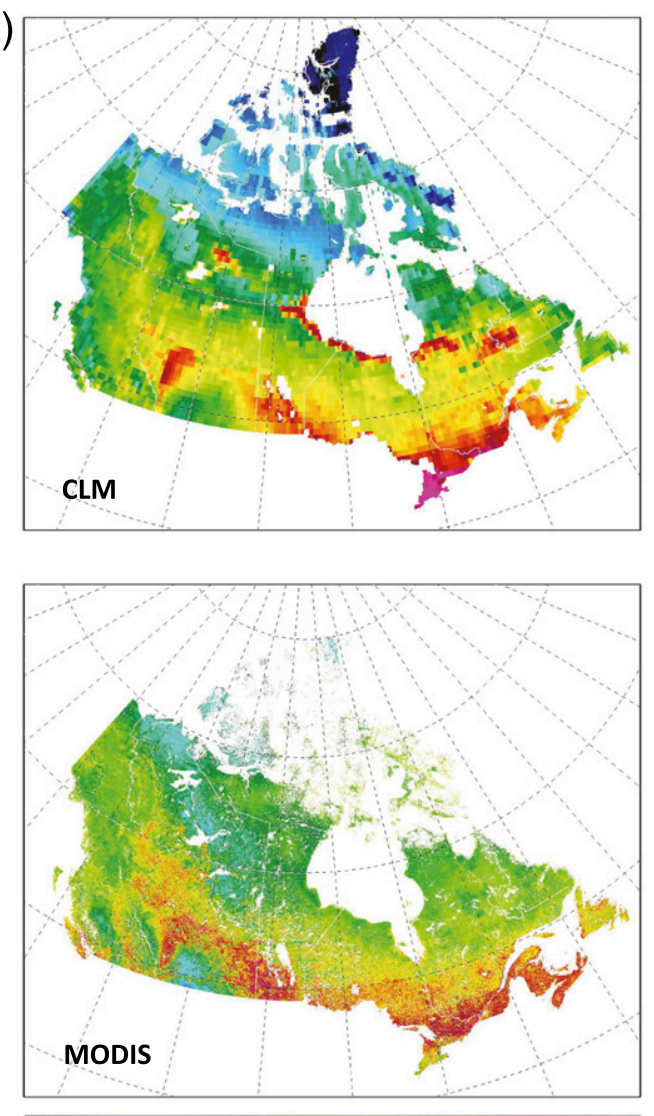

0 30

60

90

120
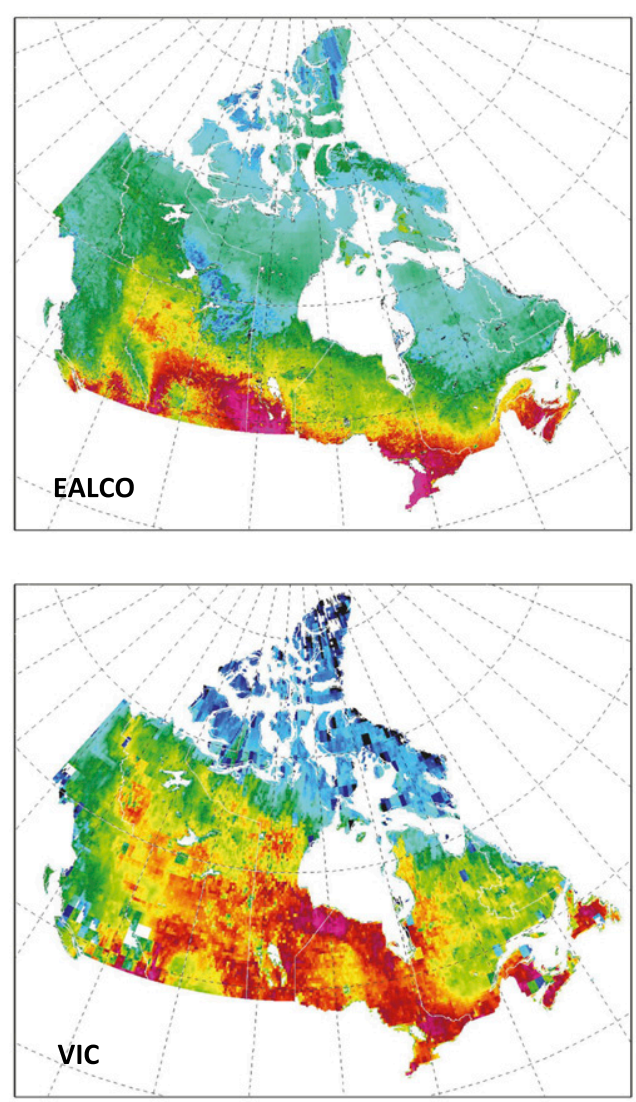

30

60

90

120

150

FIG. 5. (a) Mean monthly ET (mm month ${ }^{-1}$ ) from CLM, EALCO, MOD16, and VIC in July. Negative values are in black. (b) Histogram of the mean monthly ET ( $2 \mathrm{~mm} \mathrm{month}^{-1}$ bins) from CLM, EALCO, MOD16, and VIC in July.

clear-cut harvest of Douglas fir in the year 2000 and is surrounded by second-growth Douglas fir forest. The ET was measured in the years immediately after the harvest, when the vegetation cover was sparse and ET was low. This resulted in the large-scale mismatch in vegetation cover between the model grids and the site. The MAE for the four models was also high, at $31 \%$ of the measured ET, for the plantation site of ON-WPP39. Since the five ET datasets represent spatial scales varying from $\sim 0.01^{\circ}$ to $0.5^{\circ}$, the degree of agreement among them would shed light on the regional representativeness of the tower measurements. Indeed, the sites located in more homogeneous regions mostly showed good agreement of ET among the five datasets (e.g., SK-OA) and vice versa (e.g., the BC-HDF00).

The monthly ET measured at the 14 sites showed remarkable seasonal changes, consistent with that discussed in section $3 \mathrm{a}(2)$. It ranged from near 0 in winter to a high of $160 \mathrm{~mm} \mathrm{month}^{-1}$ in July. Negative ET was not found in the measured datasets. There were almost
$25 \%$ of the months having ET $<5 \mathrm{~mm} \mathrm{month}^{-1}$ and less than $5 \%$ of the months having ET $>100 \mathrm{~mm} \mathrm{month}^{-1}$. Of the high ET values, two-thirds were from SK-OA. All models explained the seasonal variations of the measured ET fairly well (Fig. 7). On average, the four models explained $79 \%(p<0.01)$ of the variance in the observed monthly ET. MOD16 showed relatively large positive bias in the low ET range (i.e., in winter), consistent with the results found in section $3 \mathrm{a}(2)$. The differences between the modeled and measured monthly ET were similar for the four models; RMSE varied around $16.7 \mathrm{~mm} \mathrm{month}^{-1}$ and MAE varied around $10.5 \mathrm{~mm}$ month $^{-1}$.

\section{c. Comparison of MOD16 and LSMs ET with water budget $\mathrm{ET}$}

The ET from MOD16 and the three LSMs for the 370 watersheds varied over a large range from under 50 to over $600 \mathrm{~mm} \mathrm{yr}^{-1}$ (Fig. 8). The water budget ET varied from a low of $<-1000$ to a high of over $700 \mathrm{~mm} \mathrm{yr}^{-1}$. Obviously, 


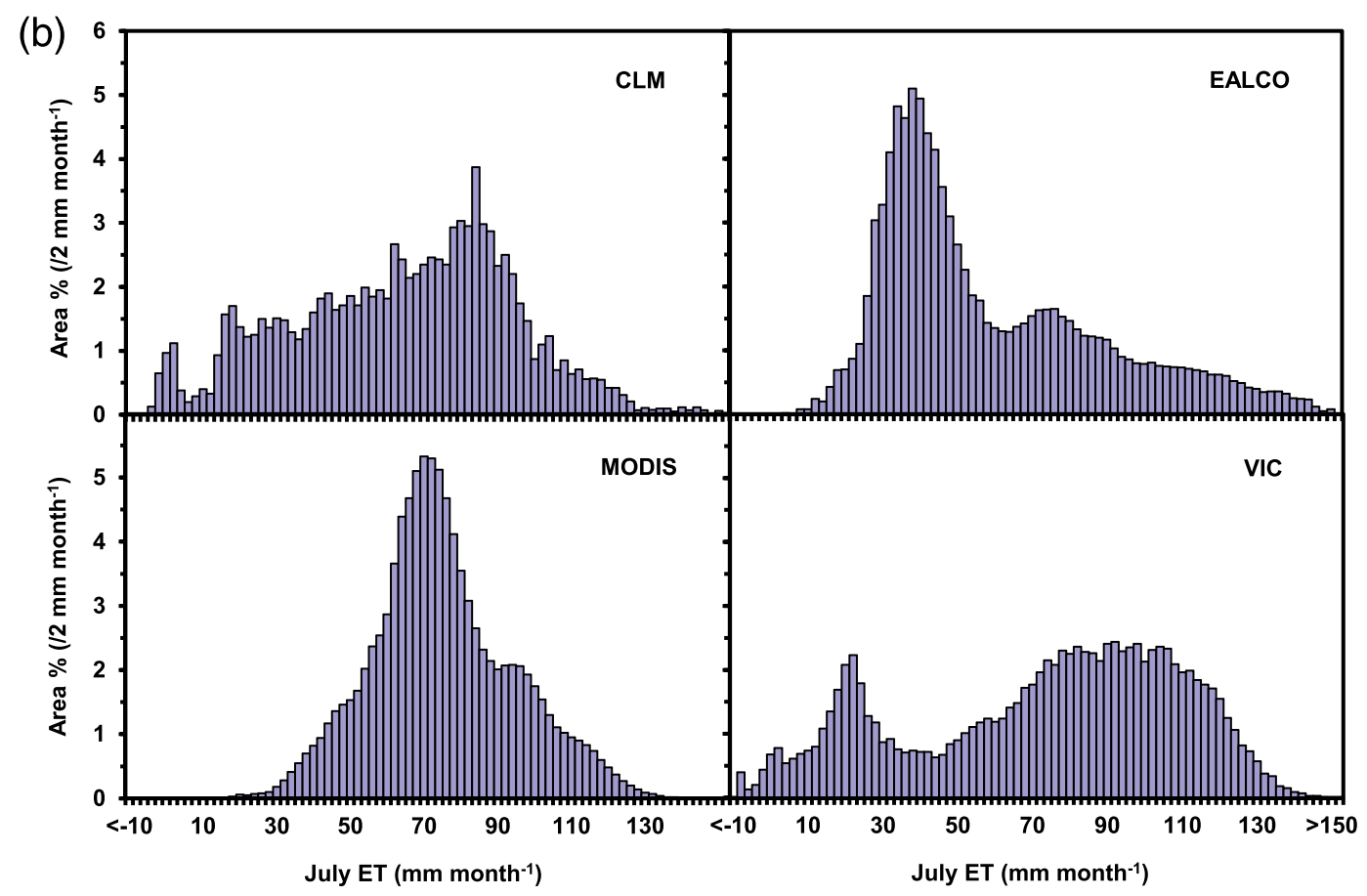

FIG. 5. (Continued)

the large negative values are unrealistic, and they were mainly due to the data quality issues in precipitation (discussed in section 4). As a result, the differences between the water budget and modeled evapotranspiration $\Delta \mathrm{ET}_{\mathrm{WB}-\text { Model }}$ varied widely among the watersheds, from under -1200 to over $300 \mathrm{~mm} \mathrm{yr}^{-1}$ (Fig. 9) or from $-80 \%$ to $40 \%$ relative to precipitation. The number of watersheds with extremely large $\Delta \mathrm{ET}_{\mathrm{WB}-\text { Model }}$ was actually small; only about $12 \%$ of the watersheds having absolute $\Delta \mathrm{ET}_{\mathrm{WB}-\text { Model }}>200 \mathrm{~mm} \mathrm{yr}^{-1}$ or $30 \%$ of precipitation. In contrast, a large number of watersheds had very small $\Delta \mathrm{ET}_{\mathrm{WB}-\text { Model }}$; more than half of the watersheds had absolute $\Delta \mathrm{ET}_{\mathrm{WB}-\text { Model }}<50 \mathrm{~mm} \mathrm{yr}^{-1}$ or $7.8 \%$ of precipitation. The results suggest that for a majority of the watersheds, the modeled ET agreed reasonably well with the water budget ET.

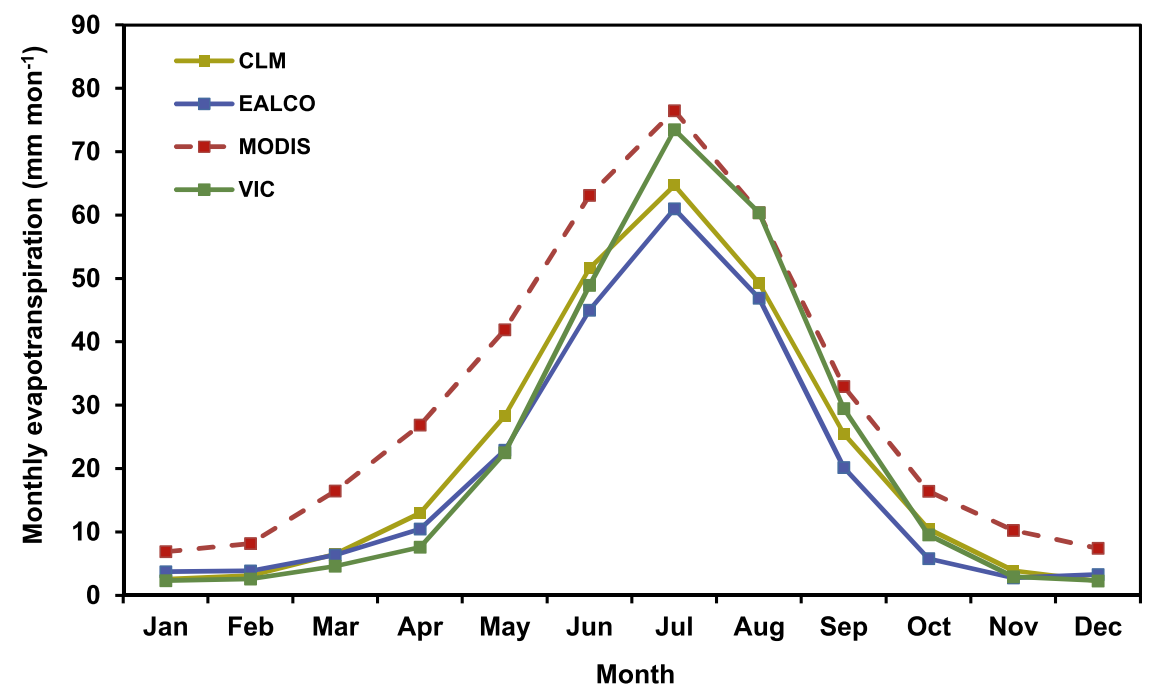

FIG. 6. Seasonal variations of the countrywide average ET for Canada from the remote sensing and LSMs. MOD16 curve is dashed as it has $25.5 \%$ areas without data, primarily over the Arctic. 


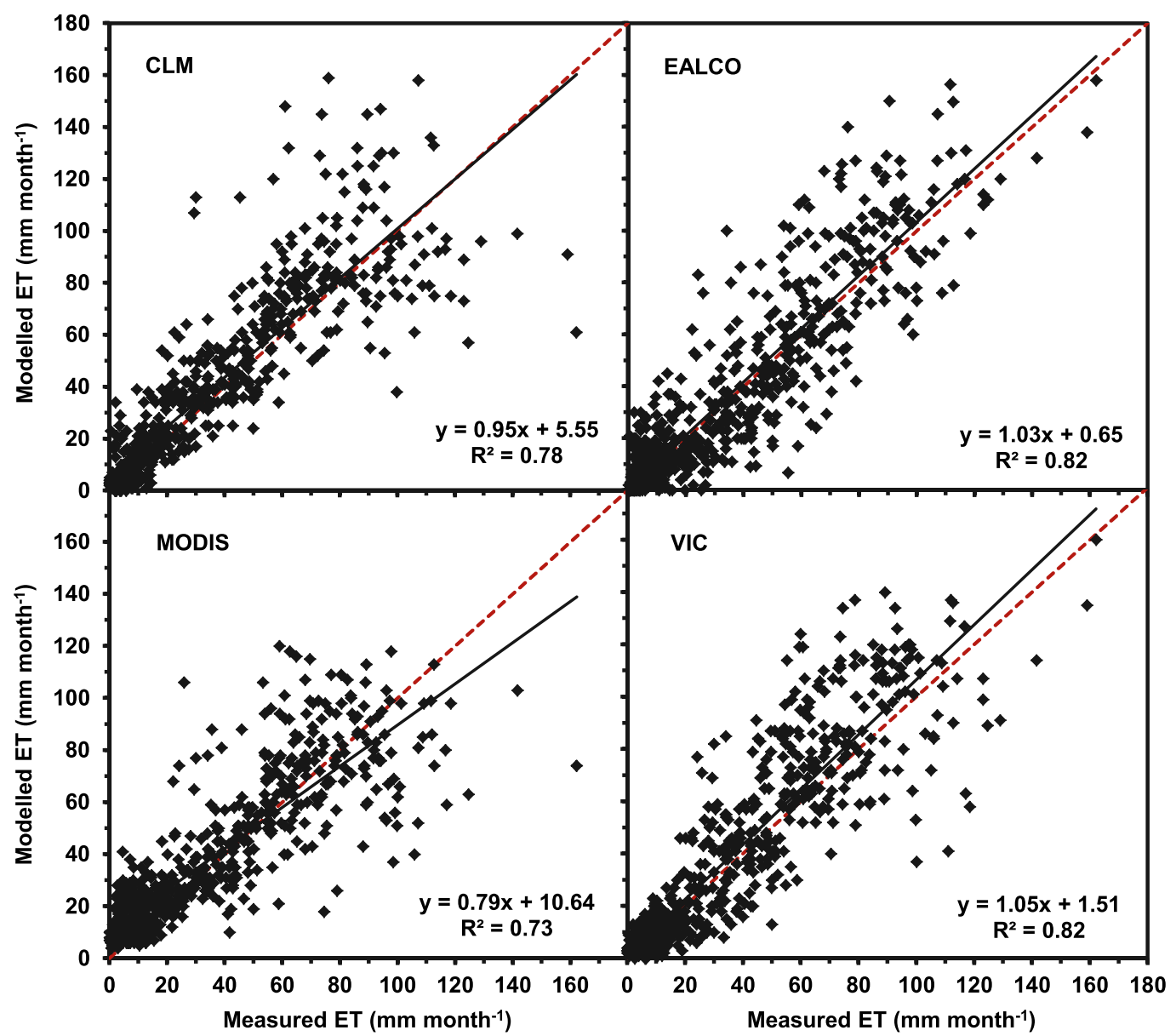

FIG. 7. Comparisons of ET from the remote sensing and LSMs with site measurements at 14 flux-tower sites.

The spatial distributions of $\Delta \mathrm{ET}_{\mathrm{WB}-\text { Model }}$ were fairly consistent among the models (Fig. 10). Watersheds with large $\Delta \mathrm{ET}_{\mathrm{WB}-\text { Model }}$ values were mainly distributed over the mountainous regions in the Pacific drainage area in the west and the St. Lawrence drainage area in the east. A closer examination revealed that the large negative $\Delta \mathrm{ET}_{\mathrm{WB}-\text { Model }}$ was mainly found in the windward sides, and the large positive $\Delta \mathrm{ET}_{\mathrm{WB}-\text { Model }}$ in the leeward sides, over the regions. Watersheds in the north mostly showed moderate values of negative $\Delta \mathrm{ET}_{\mathrm{WB}-\text { Model }}$. However, considering that the water cycle was weak with low $P$ and $\mathrm{ET}$ in the north, the values of $\Delta \mathrm{ET}_{\mathrm{WB}-\text { Model }}$ relative to precipitation were actually similar to those over the mountainous regions. Watersheds in the south-central region (e.g., the Canadian Prairies and the surrounding boreal forests) mostly showed small and positive $\Delta \mathrm{ET}_{\mathrm{WB}-\text { Model }}$. This region also demonstrated the best agreement in ET among the four models.

For a more quantitative comparison, we selected a subset of the watersheds by removing those with significantly problematic water budget ET using a fairly loose criteria of $\Delta \mathrm{ET}_{\mathrm{WB}-\text { Model }}>70 \%$ of the average $\mathrm{ET}$ by the four models. Note that the filtering was only applied to the mountainous regions in the Pacific and St. Lawrence drainage areas. We also removed the watersheds with $Q$ data records shorter than 3 years to reduce the possible impact of water storage change on the ET estimation by the water budget. For MOD16 comparison, we further removed 27 watersheds that had data gaps $>10 \%$. As a result, 309 watersheds were left for comparison with CLM, EALCO, and VIC, and 138 for MOD16.

Linear regression analyses showed that CLM and EALCO explained more than $75 \%$ of the variance in the water budget ET among the watersheds (Fig. 11). VIC ET also showed a fairly good correlation with the water budget ET, except for a few watersheds with much lower modeled values in the Atlantic Maritime. MOD16 showed large differences for watersheds in the West Cordillera and the north. The all-watershed average bias and RMSE values were 28.5 and 79.4, -13.6 and 76.3, 34.8 and 100.2 , and 25.3 and $103.3 \mathrm{~mm} \mathrm{yr}^{-1}$ for CLM, 


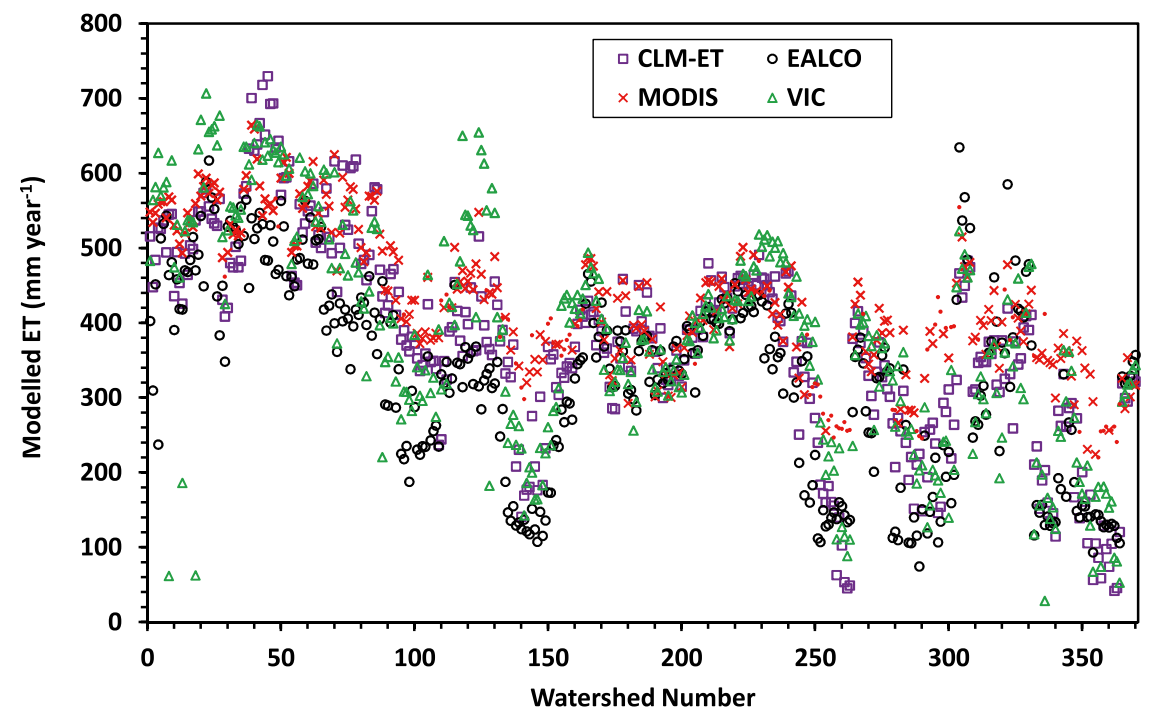

FIG. 8. Watershed ET from the remote sensing and LSMs. The red crosses represent MOD16 for the 75 watersheds having $>10 \%$ of data gaps.

EALCO, MOD16, and VIC, respectively. The watersheds have large differences in drainage areas (Table S1). Values of the area-weighted average biases, which are more representative of the landmass, were 46.5, 6.2, 100.3 , and $50.9 \mathrm{~mm} \mathrm{yr}^{-1}$ for CLM, EALCO, MOD16, and VIC, respectively.
At the ecozone scale (Fig. 12), the differences between the water budget ET and modeled ET were somewhat lower with an RMSE of 58.3,60.0, and $67.3 \mathrm{~mm} \mathrm{yr}^{-1}$ for CLM, EALCO, and VIC, respectively. MOD16 had five ecozones with data gaps $>10 \%$. For the rest of the eight ecozones, the RMSE was $140 \mathrm{~mm} \mathrm{yr}^{-1}$. The
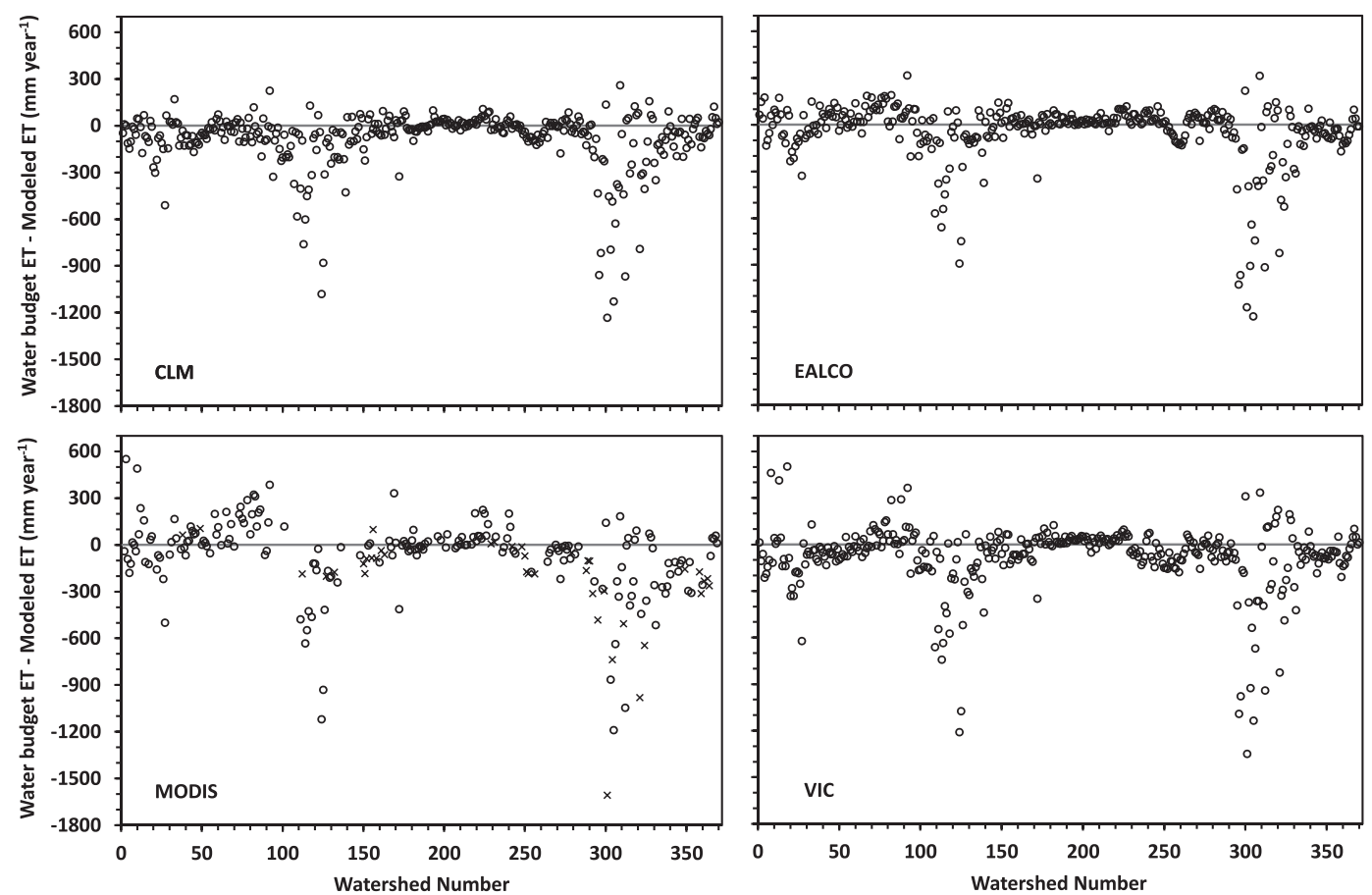

FIG. 9. Differences between the watershed ET from the surface water budget approach and the remote sensing and LSMs. CLM, EALCO, and VIC are compared for 370 watersheds. MOD16 is compared for 236 watersheds as 134 watersheds have no $Q$ measurement during 2000-10. MOD16 has 39 watersheds with ET data gaps $>10 \%$ (represented by crosses). 


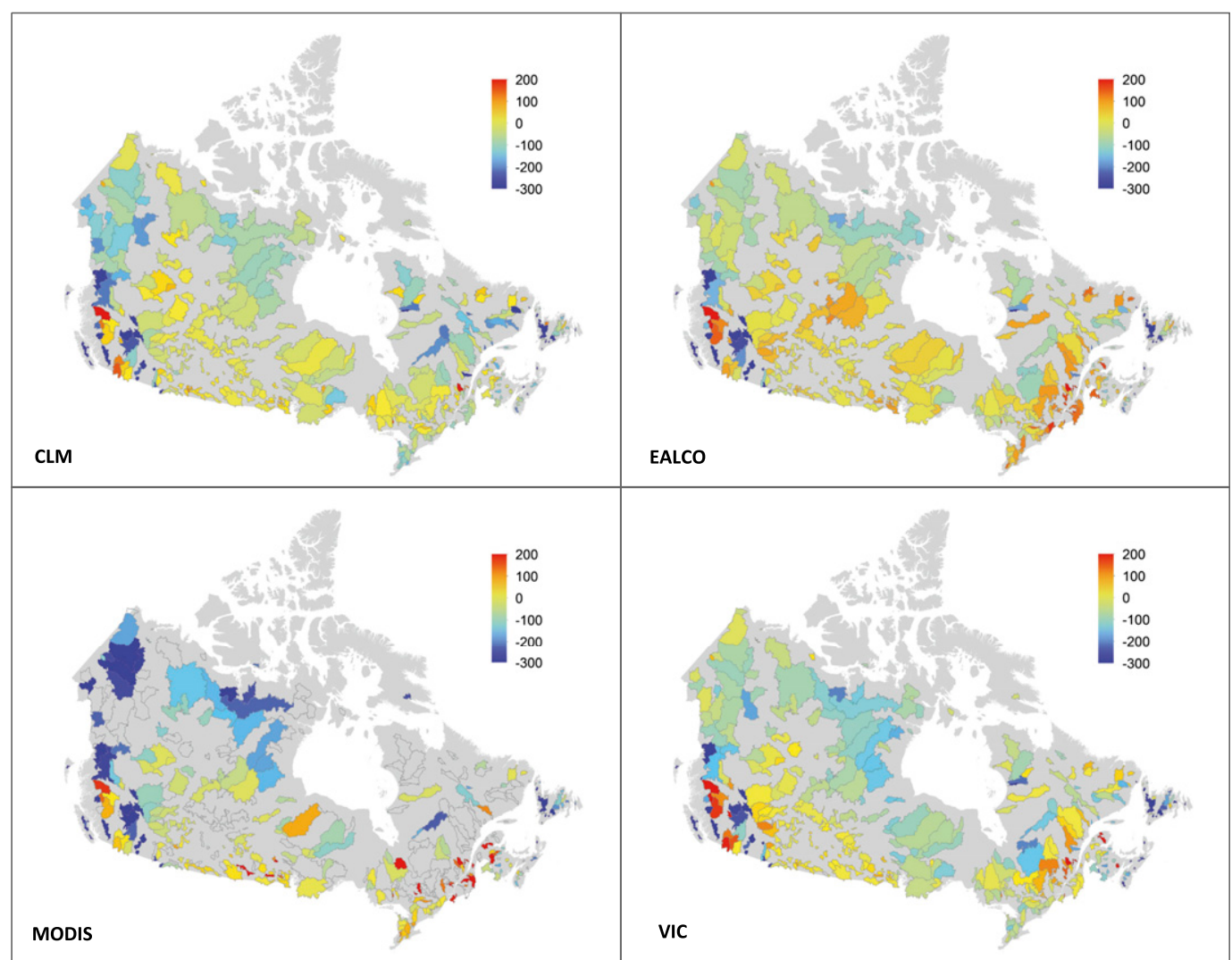

FIG. 10. Maps of the differences between the watershed ET $\left(\mathrm{mm} \mathrm{yr}^{-1}\right)$ from the water budget approach and the remote sensing and LSMs. Note that some watersheds for MOD16 have large data gaps (see in Fig. 2).

decrease in ET uncertainty with larger spatial scales is mainly due to the offset of the positive and negative biases within the region. For example, the Montane Cordillera ecozone contains watersheds with very high values of $\Delta \mathrm{ET}_{\mathrm{WB}-\text { Model }}$, but its ecozone-level $\Delta \mathrm{ET}_{\mathrm{WB}-\text { Model }}$ became very small $\left(16.3 \mathrm{~mm} \mathrm{yr}^{-1}\right.$ or $4 \%)$. On average for the four models, ecozone $\Delta \mathrm{ET}_{\mathrm{WB}-\text { Model }}$ varied within from $-5 \%$ to $6 \%$ of the water budget ET for half of the ecozones, which included Boreal Plain, Atlantic Maritime, Hudson Plain, Boreal Shield, Mixed Wood Plain, Prairie, and Montane Cordillera. Relatively small differences were also found for EALCO over the Taiga Plain and Taiga Shield ecozones and for CLM over the Taiga Plain ecozone. For other ecozones, all the models showed substantially higher ET than that from the water budget. The differences were especially pronounced for the two Arctic ecozones and for the Taiga and Boreal Cordillera ecozones by MOD16. The differences in ET among the three LSMs at the ecozone scale were very small. The bias and RMSE for CLM, EALCO, and VIC estimates with respect to their means was only 11.3 and 27.7, -25.7 and 42.5 , and 14.4 and $29.0 \mathrm{~mm} \mathrm{yr}^{-1}$, respectively.

\section{Discussion}

Flux measurement is affected by site and instrument conditions and various errors from measurement, data gap-filling, and processing. This study relied on monthly and annual ET aggregated from the existing FCRN studies operated using similar measurement techniques and data-processing protocols, thereby reducing the ET uncertainty among the sites. The estimates of uncertainty in ET for our study sites were not available during the period of the study. Ryu et al. (2008) reported an overall uncertainty in EC-measured ET of $8.8 \%$ at the $90 \%$ confidence level over a grassland in California. Krishnan et al. (2012) estimated the uncertainty in annual ET over two temperate semiarid grasslands in North America and found that the uncertainty in ET associated with the gap-filling procedure was $6.6 \%$ at the $95 \%$ confidence level. In another study over SK-OA, Krishnan et al. (2006) reported that the uncertainty in annual net ecosystem productivity due to the random error in half-hourly $\mathrm{CO}_{2}$ fluxes was less than $20 \%$ of the uncertainty from the gap-filling procedure, suggesting that the uncertainty in ET due to the random error in measurement was small. Uncertainties in the 


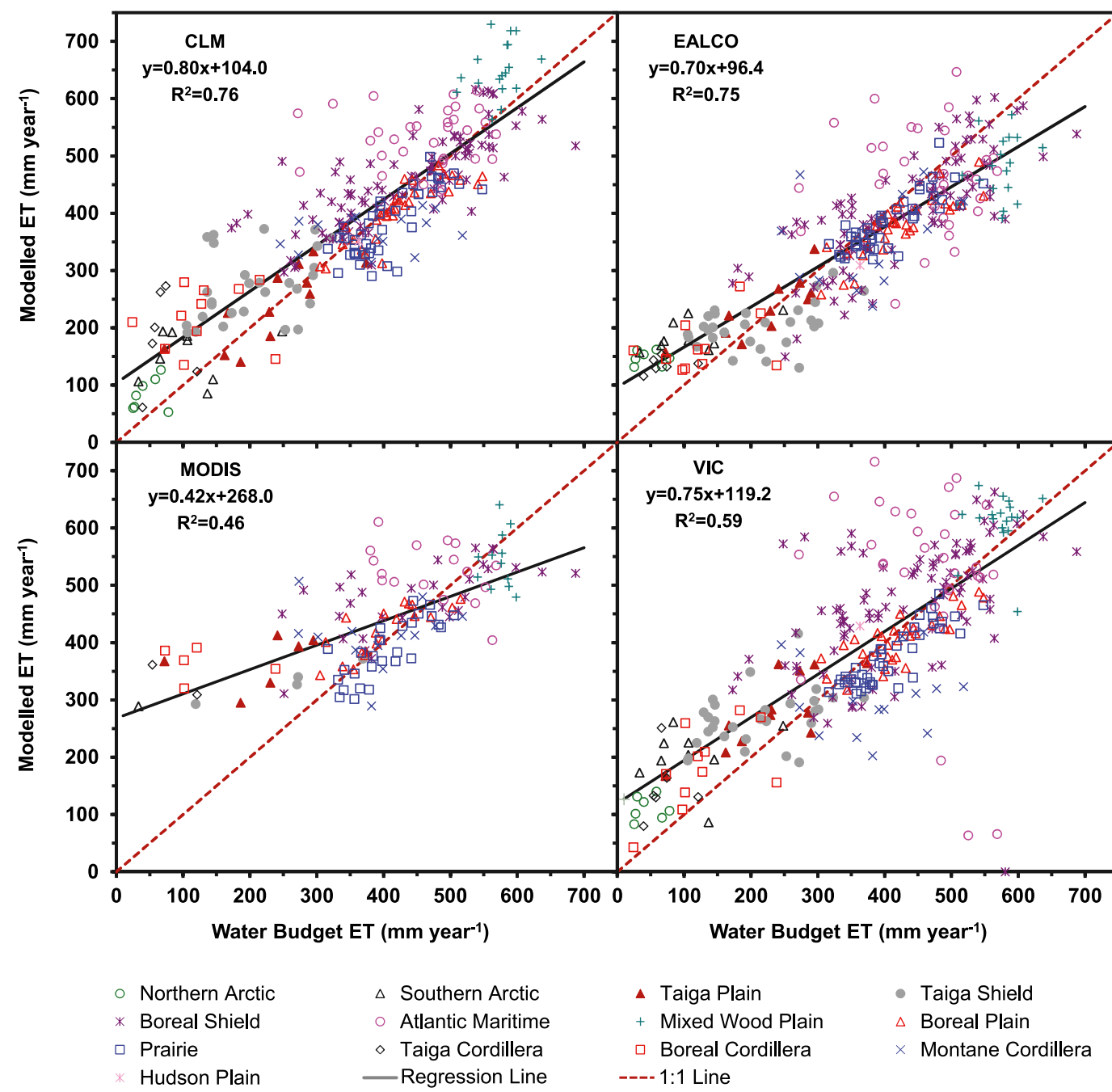

FIG. 11. Comparisons of watershed ET from the surface water budget approach and the remote sensing and LSMs. CLM, EALCO, and VIC are compared for 309 watersheds. MOD16 is compared for 138 watersheds (watersheds with data gap $>10 \%$ are excluded).

EC-measured monthly ET in our study regions still need to be quantified.

The EC measurements represent the most direct and accurate ET estimates at the local scale and provide a data source for model calibrations and validations. However, tower-based ET has large limitations in regional-scale applications since the flux footprint, which varies with wind, thermal stability, surface roughness, and measurement height, is usually limited to a few kilometers from the flux tower (Zhang et al. 2012). Our results showed that the correlations between the modeled and measured ET decreased substantially with the decrease in model spatial resolution (Table 1), suggesting a mismatch of scales and emphasizing the importance of upscaling site-level measurement in regional studies. Moreover, the large data gap over the north and the sparse spatial coverage in the south for the EC measurements made it difficult for more rigorous model calibrations and validations at the national scale. The impact of this limitation appears more significant on the MODIS model as it lacked full constraints in energy and water balances and relied more on observed parameters. Not surprisingly, MOD16 showed relatively large differences compared with other datasets in cold seasons and in sparsely vegetated land surfaces where observations are scarce. The three LSMs showed relatively small differences in ET among them and with the water budget approach, although ET values were calculated independently using different atmospheric forcings and land surface (e.g., vegetation and soil) data inputs. 


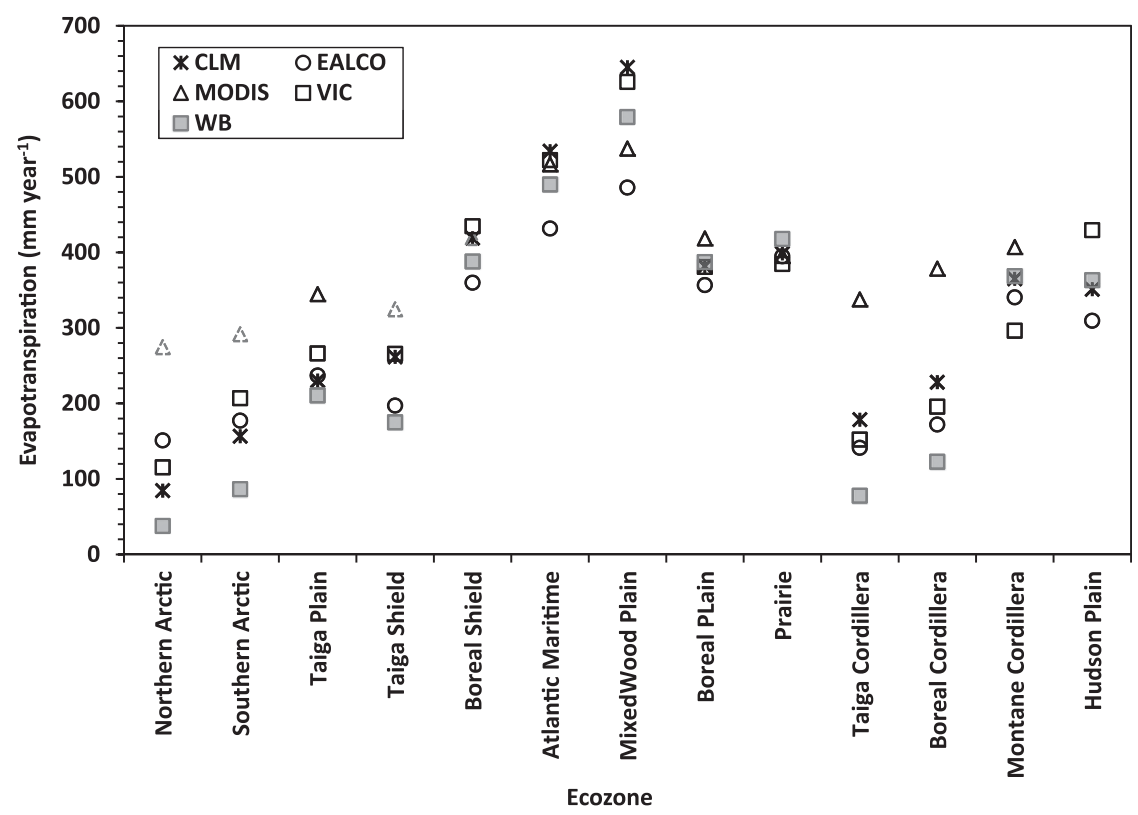

FIG. 12. Comparisons of ecozone ET from the surface water budget approach and the remote sensing and LSMs. MOD16 has data gaps $>10 \%$ for five ecozones as represented by the dashed triangles.

ET from the surface water budget approach is often deemed the most reliable estimate for watersheds, and it has been frequently used to benchmark other approaches in regional-scale studies. This is contingent on the assumptions that $P$ and $Q$ are reasonably accurate and water storage change is negligible so that the water budget can be adequately closed for a watershed. In practice, these assumptions can be challenged, as demonstrated by our results for mountainous regions and the north. These regions are difficult to access and poorly monitored. The harsh environment also brings large measurement errors. For example, studies show that the measurement errors in precipitation can be as high as $50 \%$ for snow under windy conditions (Sevruk 1982; WMO 2008). The negative $\Delta \mathrm{ET}_{\mathrm{WB}-\text { Model }}$ in the north was likely due to the underestimation of water budget ET from the undercatch of snow. Indeed, we found that a number of watersheds in these regions had suspicious values of $P$ that were unreasonably close to or sometimes even smaller than the values of $Q$ (e.g., watershed 359, 107, 139, and 334; see Table S1). Moreover, $P$ in mountainous regions varied substantially in space while $P$ on windward sides or high-elevation areas could be considerably higher than that on the leeward sides or low-elevation rain-shadow areas. Unfortunately, climate stations in mountainous regions are extremely sparse and they are mostly located in valleys where people live. This biased sampling largely limits the spatial representativeness of the measurements. For example, 9 out of the 12 watersheds in the Pacific Maritime ecozone showed that $P$ was smaller than $Q$. Obviously, the large negative $\Delta \mathrm{ET}_{\mathrm{WB}-\text { Model }}$ values found for the windward watersheds were due to the underestimation of $P$ and hence water budget ET, and vice versa for the leeward watersheds. The spatial interpolation model for $P$ used in this study also introduces additional uncertainties, which were reported to be in the range of $20 \%-40 \%$ (McKenney et al. 2006). In Wang et al. (2014a), $P$ was compared with global reanalysis values of $P$ reported by Sheffield et al. (2006) and the differences were found to have similar magnitudes to those from the error analysis in McKenney et al. (2006). Not surprisingly, the interpolated $P$ errors exhibited the highest values over mountainous and northern regions because of the low gauge density. In contrast, the south-central region has relatively more climate stations and small variations in topography and is deemed to have the least uncertainty in the $P$ product. Indeed, the water budget ET over this region had the best agreement with the modeled ET.

The spatially and temporally integrated $Q$ can be measured at a regional level (Pan and Wood 2013). Under optimal measurement conditions and with the assumption of uniformity in uncertainty within the global hydrometric dataset, it is generally accepted that the uncertainty of daily mean $Q$ is $5 \%$ at the $95 \%$ confidence interval (Herschy 1999). However, the measurement of $Q$ under freezing and low-flow conditions, which are not unusual for most Canadian rivers, can involve substantial 
uncertainties. The detailed analyses of Canadian $Q$ data have suggested that under various situations the uncertainty in $Q$ values could well exceed the theoretical uncertainty that is generally assumed for the typical global hydrometric dataset and remains to be quantified (Hamilton 2008; Hamilton and Moore 2012). Overestimation of $Q$ in some northern watersheds could have contributed to the underestimation of water budget ET.

The assumption of negligible water storage change in water budget ET estimates is deemed reasonable, as most of the watersheds in this study have data for more than 15-20 years. However, climate change and anthropogenic disturbances may change the hydrological state of some watersheds, which leads to long-term trends in water storage. For example, consistent shrinkage in glacier and snow extent and degradation in permafrost have been recently reported (e.g., Spence 2002; Déry et al. 2009; St. Jacques and Sauchyn 2009; Walvoord et al. 2012), which may result in significant long-term changes in water storage. Some of our studied watersheds in the north, particularly those in the glaciated regions (e.g., the Yukon basin), may have been impacted. Observations by the GRACE satellites have been used recently to quantify the decadal changes in water storage for large Canadian basins (Wang et al. 2015). Unfortunately, the large footprint of GRACE limits its applications in this study. Quantifying the long-term water storage change at the watershed scale and its impact on water budget ET estimates needs to be addressed in further studies. Additionally, some local processes, such as blowing snow redistribution and sublimation over the Canadian Prairies and the northern tundra regions, also need to be addressed in the water budget ET estimates for watersheds in certain regions.

\section{Conclusions}

The six ET datasets showed large variations in ET values with latitude, season, and topography over Canada's landmass (energy constrained) and depressed values over the Canadian Prairies in summer (water constrained). Spatially, the mean annual ET varies from small negative values (net water vapor condensation) to over $600 \mathrm{~mm}$ across the landmass, with a countrywide average of $256 \pm 15 \mathrm{~mm}$, based on LSM products. Seasonally, the countrywide averages change dramatically from a low of about $3 \mathrm{~mm}$ month $^{-1}$ in four winter months (November-February) to a high of $67 \pm 7 \mathrm{~mm} \mathrm{month}^{-1}$ in July. ET in the three summer months of June-August accounted for $66 \% \pm 3 \%$ of the annual total. ET at different spatial scales (watershed, ecozone, and national) showed that the uncertainty is scale dependent. Mean ET for larger regions tends to have smaller uncertainties due to the cancellation of the positive and negative biases within the region.

The EC-measured ET represents the most direct and accurate estimate at the local scale but is only available for a very limited number of sites in Canada. The water budget approach estimates ET at watershed scale but suffers from the uncertainties in $P$ and $Q$ estimates, which were found to be large in mountainous regions and in the north. MODIS ET has the advantage of using the high-resolution surface parameters from MODIS observations and fewer requirements for atmosphere forcings than the LSMs (e.g., MOD16 model needs no precipitation data as input), but it lacks full constraints in energy and water balances and relies more on observed parameters. MOD16 showed relatively large differences when compared with other datasets in cold seasons and sparsely vegetated regions. Both water budget and MODIS products have large data gaps in the Arctic, making it difficult to use them for making countrywide estimates. The LSM products have full coverage of the landmass and were found to have small uncertainties.

Extending ET measurements to more sites, especially over the north, is critical to further constraining remote sensing products and LSMs and improving national-scale ET estimates. The amount of water vapor condensation in LSMs was found to be substantial, especially in winter and in the Arctic. The current ET dataset from EC does not include negative ET values, which limits its applications in calibrating and validating the dew and frost formation processes in LSMs. Data quality issues, especially for precipitation, due to the poor spatial representativeness of weather stations in mountainous regions or the underestimation of snow under windy conditions challenge the surface water budget approach for accurately estimating ET for watersheds over complex terrains and the north. Enhancing the climate and hydrological observation networks and data quality controls over these regions is imperative. Examinations of the $P$ datasets from other approaches, such as PRISM (Daly et al. 2008) or Canadian Precipitation Analysis (CaPA; Mahfouf et al. 2007), need to be conducted next. More model validations and improvement in spatial resolution are necessary for improving ET estimates in LSMs. Future techniques should also consider a hybrid approach that integrates strengths of the various ET products to help reduce uncertainties in the estimation of ET.

Acknowledgments. This work was supported by the Groundwater Geoscience Program and Remote Sensing Science Program of the Earth Science Sector (ESS), Natural Resources Canada. We thank Dr. D.W. McKenney and Ms. P. Papadopol of Canadian Forest 
Service for providing the precipitation data. The EC ET measurements were made as a part of the Fluxnet Canada Research Network (FCRN) and Canada Carbon Program (CCP), which were funded by the Canadian Foundation for Climate and Atmospheric Sciences (CFCAS), the Natural Sciences and Engineering Research Council (NSERC), and BIOCAP Canada. CLM data production is supported by the U.S. Department of Energy (DOE), Office of Science, Biological and Environmental Research. Oak Ridge National Laboratory is managed by UT-BATTELLE for the DOE under Contract DE-AC05-00OR22725.

\section{REFERENCES}

Agriculture and Agri-Food Canada, 1996: Soil Landscapes of Canada, version 2.2. Centre for Land and Biological Resources Research, accessed 31 March 2003. [Available online at http://sis.agr.gc.ca/cansis/nsdb/slc/v2.2/index.html.]

Brümmer, C., and Coauthors, 2012: How climate and vegetation type influence evapotranspiration and water use efficiency in Canadian forest, peatland and grassland ecosystems. Agric. For. Meteor., 153, 14-30, doi:10.1016/j.agrformet.2011.04.008.

Cleugh, H. A., R. Leuning, Q. Mu, and S. W. Running, 2007: Regional evaporation estimates from flux tower and MODIS satellite data. Remote Sens. Environ., 106, 285-304, doi:10.1016/ j.rse.2006.07.007.

Daly, C., M. Halbleib, J. I. Smith, W. P. Gibson, M. K. Doggett, G. H. Taylor, J. Curtis, and P. P. Pasteris, 2008: Physiographically sensitive mapping of climatological temperature and precipitation across the conterminous United States. Int. J. Climatol., 28, 2031-2064, doi:10.1002/joc.1688.

De Kauwe, M., and Coauthors, 2013: Forest water use and water use efficiency at elevated $\mathrm{CO}_{2}$ : A model-data intercomparison at two contrasting temperate forest FACE sites. Global Change Biol., 19, 1759-1779, doi:10.1111/gcb.12164.

— , and Coauthors, 2014: Where does the carbon go? A modeldata intercomparison of vegetation carbon allocation and turnover processes at two temperate forest free-air $\mathrm{CO}_{2}$ enrichment sites. New Phytol., 203, 883-899, doi:10.1111/nph.12847.

Déry, S. J., M. A. Hernández-Henríquez, J. E. Burford, and E. F. Wood, 2009: Observational evidence of an intensifying hydrological cycle in northern Canada. Geophys. Res. Lett., 36, L13402, doi:10.1029/2009GL038852.

Fernandes, R., V. Korolevych, and S. Wang, 2007: Trends in land evapotranspiration over Canada for the period 1960-2000 based on in situ climate observations and a land surface model. J. Hydrometeor., 8, 1016-1030, doi:10.1175/JHM619.1.

Fisher, J. B., K. Tu, and D. D. Baldocchi, 2008: Global estimates of the land-atmosphere water flux based on monthly AVHRR and ISLSCP-II data, validated at FLUXNET sites. Remote Sens. Environ., 112, 901-919, doi:10.1016/j.rse.2007.06.025.

Friedl, M. A., and Coauthors, 2002: Global land cover mapping from MODIS: Algorithms and early results. Remote Sens. Environ., 83, 287-302, doi:10.1016/S0034-4257(02)00078-0.

Githui, F., B. Selle, and T. Thayalakumaran, 2012: Recharge estimation using remotely sensed evapotranspiration in an irrigated catchment in southeast Australia. Hydrol. Processes, 26, 1379-1389, doi:10.1002/hyp.8274.

Global Soil Data Task, 2000: Global Soil Data Products CD-ROM (IGBP-DIS). Oak Ridge National Laboratory Distributed
Active Archive Center, accessed 22 May 2002. [Available online at http://daac.ornl.gov/SOILS/guides/igbp.html.]

Grant, R. F., and Coauthors, 2005: Intercomparison of techniques to model high temperature effects on $\mathrm{CO}_{2}$ and energy exchange in temperate and boreal coniferous forests. Ecol. Modell., 188, 217-252, doi:10.1016/j.ecolmodel.2005.01.060.

—, and Coauthors, 2006: Intercomparison of techniques to model water stress effects on $\mathrm{CO}_{2}$ and energy exchange in temperate and boreal deciduous forests. Ecol. Modell., 196, 289-312, doi:10.1016/j.ecolmodel.2006.02.035.

Gutman, G., and A. Ignatov, 1998: The derivation of the green vegetation fraction from NOAA/AVHRR data for use in numerical weather prediction models. Int. J. Remote Sens., 19, 1533-1543, doi:10.1080/014311698215333.

Hamilton, A. S., 2008: Sources of uncertainty in Canadian low flow hydrometric data. Can. Water Resour. J., 33, 125-136, doi:10.4296/ cwrj3302125.

—_, and R. D. Moore, 2012: Quantifying uncertainty in streamflow records. Can. Water Resour. J., 37, 3-21, doi:10.4296/cwrj3701865.

Hansen, M. C., R. S. DeFries, J. R. G. Townshend, and R. Sohlberg, 2000: Global land cover classification at $1 \mathrm{~km}$ spatial resolution using a classification tree approach. Int. J. Remote Sens., 21, 1331-1364, doi:10.1080/014311600210209.

Hanson, P. J., and Coauthors, 2004: Oak forest carbon and water simulations: Model intercomparisons and evaluations against independent data. Ecol. Monogr., 74, 443-489, doi:10.1890/03-4049.

Herschy, R. W., 1999: Uncertainties in hydrometric measurements. Hydrometry Principles and Practices, 2nd ed. R.W. Herschy, Ed., John Wiley \& Sons, 355-370.

Hurtt, G., S. Frolking, M. Fearon, B. Moore, E. Shevliakova, S. Malyshev, S. Pacala, and R. Houghton, 2006: The underpinnings of land use history: Three centuries of global gridded land use transitions, wood harvest activity, and resulting secondary lands. Global Change Biol., 12, 1208-1229, doi:10.1111/j.1365-2486.2006.01150.x.

Jassal, R. S., T. A. Black, D. L. Spittlehouse, C. Brümmer, and Z. Nesic, 2009: Evapotranspiration and water use efficiency in different-aged Pacific Northwest Douglas-fir stands. Agric. For. Meteor., 149, 1168-1178, doi:10.1016/j.agrformet.2009.02.004.

Jung, M., and Coauthors, 2010: Recent decline in the global land evapotranspiration trend due to limited moisture supply. $\mathrm{Na}$ ture, 467, 951-954, doi:10.1038/nature09396.

Koster, R. D., and P. C. D. Milly, 1997: The interplay between transpiration and runoff formulations in land surface schemes used with atmospheric models. J. Climate, 10, 1578-1591, doi:10.1175/1520-0442(1997)010<1578:TIBTAR>2.0.CO;2.

Krishnan, P., T. A. Black, N. J. Grant, A. G. Barr, E. T. H. Hogg, R. S. Jassal, and K. Morgenstern, 2006: Impact of changing soil moisture distribution on net ecosystem productivity of a boreal aspen forest during and following drought. Agric. For. Meteor., 139, 208-223, doi:10.1016/j.agrformet.2006.07.002. -, T. P. Meyers, R. L. Scott, L. Kennedy, and M. Heuer, 2012: Energy exchange and evapotranspiration over two temperate semi-arid grasslands in North America. Agric. For. Meteor., 153, 31-44, doi:10.1016/j.agrformet.2011.09.017.

Lathuillière, M. J., M. S. Johnson, and S. D. Donner, 2012: Water use by terrestrial ecosystems: Temporal variability in rainforest and agricultural contributions to evapotranspiration in Mato Grosso, Brazil. Environ. Res. Lett., 7, 024024, doi:10.1088/1748-9326/7/2/024024.

Lawrence, D. M., P. E. Thornton, K. W. Oleson, and G. B. Bonan, 2007: The partitioning of evapotranspiration into transpiration, soil evaporation, and canopy evaporation in a GCM: 
Impacts on land-atmosphere interaction. J. Hydrometeor., 8 , 862-880, doi:10.1175/JHM596.1.

Liang, X., D. P. Lettenmaier, E. F. Wood, and S. J. Burges, 1994: A simple hydrologically based model of land-surface water and energy fluxes for general-circulation models. J. Geophys. Res., 99, 14 415-14 428, doi:10.1029/94JD00483.

_ , E. F. Wood, and D. P. Lettenmaier, 1996: Surface soil moisture parameterization of the VIC-2L model: Evaluation and modification. Global Planet. Change, 13, 195-206, doi:10.1016/ 0921-8181(95)00046-1.

Loarie, S. R., D. B. Lobell, G. P. Asner, Q. Mu, and C. B. Field, 2011: Direct impacts on local climate of expanding sugarcane in Brazil. Nat. Climate Change, 1, 105-109, doi:10.1038/ nclimate1067.

Long, D., L. Longuevergne, and B. R. Scanlon, 2014: Uncertainty in evapotranspiration from land surface modeling, remote sensing, and GRACE satellites. Water Resour. Res., 50, 11311151, doi:10.1002/2013WR014581.

Los, S. O., and Coauthors, 2000: A global 9-yr biophysical land surface dataset from NOAA AVHRR data. J. Hydrometeor., 1, 183-199, doi:10.1175/1525-7541(2000)001<0183:AGYBLS>2.0.CO;2.

Mahfouf, J. F., B. Brasnett, and S. Gagnon, 2007: A Canadian precipitation analysis (CaPA) project: Description and preliminary results. Atmos.-Ocean, 45, 1-17, doi:10.3137/ao.450101.

Mao, J., P. E. Thornton, X. Shi, M. Zhao, and W. M. Post, 2012: Remote sensing evaluation of CLM4 GPP for the period 200009. J. Climate, 25, 5327-5342, doi:10.1175/JCLI-D-11-00401.1.

— - X. Shi, P. Thornton, F. Hoffman, Z. Zhu, and R. Myneni, 2013: Global latitudinal-asymmetric vegetation growth trends and their driving mechanisms: 1982-2009. Remote Sens., 5, 1484-1497, doi:10.3390/rs5031484.

McKenney, D. W., J. H. Pedlar, P. Papadopol, and M. F. Hutchinson, 2006: Development of 1901-2000 historical monthly climate models for Canada and the United States. Agric. For. Meteor., 138, 69-81, doi:10.1016/j.agrformet.2006.03.012.

— , and Coauthors, 2011: Customized spatial climate models for North America. Bull. Amer. Meteor. Soc., 92, 1611-1622, doi:10.1175/2011BAMS3132.1.

Mi, N., G. R. Yu, X. F. Wen, X. M. Sun, S. Wang, L. M. Zhang, and X. Song, 2009: Use of ecosystem flux data and a simulation model to examine seasonal drought effects on a subtropical coniferous forest. Asia-Pac. J. Atmos. Sci., 45, 207-220.

Miller, D. A., and R. A. White, 1998: A conterminous United States multilayer soil characteristics dataset for regional climate and hydrology modeling. Earth Interact., 2, doi:10.1175/ 1087-3562(1998)002<0001:ACUSMS >2.3.CO;2.

Mitchell, K. E., and Coauthors, 2004: The multi-institution North American Land Data Assimilation System (NLDAS): Utilizing multiple GCIP products and partners in a continental distributed hydrological modeling system. J. Geophys. Res., 109, D07S90, doi:10.1029/2003JD003823.

Mlynowski, T. J., M. A. Hernández-Henríquez, and S. J. Déry, 2011: An evaluation of hydrometric monitoring across the Canadian pan-Arctic region, 1950-2008. Hydrol. Res., 42, 479490, doi:10.2166/nh.2011.105.

Molders, N., and A. Raabe, 1996: Numerical investigations on the influence of subgrid-scale surface heterogeneity on evapotranspiration and cloud processes. J. Appl. Meteor., 35, 782-795, doi:10.1175/1520-0450(1996)035<0782:NIOTIO>2.0.CO;2.

Monteith, J. L., and M. H. Unsworth, 1990: Principles of Environmental Physics. 2nd ed. Routledge, $291 \mathrm{pp}$.

Montenegro, A., M. Eby, Q. Mu, M. Mulligan, A. J. Weaver, E. C. Wiebe, and M. Zhao, 2009: The net carbon drawdown of small scale afforestation from satellite observations. Global Planet. Change, 69, 195-204, doi:10.1016/j.gloplacha.2009.08.005.

Mu, Q., F. A. Heinsch, M. Zhao, and S. W. Running, 2007a: Development of a global evapotranspiration algorithm based on MODIS and global meteorology data. Remote Sens. Environ., 111, 519-536, doi:10.1016/j.rse.2007.04.015.

_- M. Zhao, F. A. Heinsch, M. Liu, H. Tian, and S. W. Running, 2007b: Evaluating water stress controls on primary production in biogeochemical and remote sensing based models. J. Geophys. Res., 112, G01012, doi:10.1029/2006JG000179.

,-- , and S. W. Running, 2011: Improvements to a MODIS global terrestrial evapotranspiration algorithm. Remote Sens. Environ., 115, 1781-1800, doi:10.1016/j.rse.2011.02.019.

Myneni, R. B., and Coauthors, 2002: Global products of vegetation leaf area and fraction absorbed PAR from year one of MODIS data. Remote Sens. Environ., 83, 214-231, doi:10.1016/ S0034-4257(02)00074-3.

Oleson, K. W., and Coauthors, 2008: Improvements to the Community Land Model and their impact on the hydrological cycle. J. Geophys. Res., 113, G01021, doi:10.1029/ 2007JG000563.

, and Coauthors, 2010: Technical description of version 4.0 of the Community Land Model (CLM). NCAR Tech. Note NCAR/TN-478+STR, 257 pp., doi:10.5065/D6FB50WZ.

Pan, M., and E. F. Wood, 2013: Inverse streamflow routing. Hydrol. Earth Syst. Sci., 17, 4577-4588, doi:10.5194/hess-17-4577-2013.

—, A. K. Sahoo, T. J. Troy, R. K. Vinukollu, J. Sheffield, and E. F. Wood, 2012: Multisource estimation of long-term terrestrial water budget for major global river basins. J. Climate, 25, 3191-3206, doi:10.1175/JCLI-D-11-00300.1.

Pavlic, G., R. Fernandes, W. Chen, R. Fraser, and S. G. Leblanc, 2002: Methods for deriving Canada wide geo-spatial datasets in support of environmental monitoring and modelling. ISPRS Commission IV Symp. Joint Int. Symp. on Geospatial Theory, Processing and Applications, Ottawa, ON, Canada, ISPRS, 6 pp. [Available online at www.isprs.org/proceedings/XXXIV/part4/ pdfpapers/384.pdf.]

Renger, M., O. Strebel, G. Wessolek, and W. H. M. Duynisveld, 2007: Evapotranspiration and groundwater recharge-A case study for different climate, crop patterns, soil properties and groundwater depth conditions. J. Plant Nutr. Soil Sci., 149, 371-381, doi:10.1002/jpln.19861490403.

Ryu, Y., D. D. Baldocchi, S. Ma, and T. Hehn, 2008: Interannual variability of evapotranspiration and energy exchange over an annual grassland in California. J. Geophys. Res., 113, D09104, doi:10.1029/2007JD009263.

Salomon, J., C. B. Schaaf, A. H. Strahler, F. Gao, and Y. Jin, 2006: Validation of the MODIS bidirectional reflectance distribution function and albedo retrievals using combined observations from the Aqua and Terra platforms. IEEE Trans. Geosci. Remote Sens., 44, 1555-1565, doi:10.1109/ TGRS.2006.871564.

Schaaf, C. B., and Coauthors, 2002: First operational BRDF, albedo and nadir reflectance products from MODIS. Remote Sens. Environ., 83, 135-148, doi:10.1016/S0034-4257(02)00091-3.

Sevruk, B., 1982: Methods of correction for systematic error in point precipitation measurement for operational use. Operational Hydrology Rep. 21/WMO 589, 91 pp.

Sheffield, J., and E. F. Wood, 2007: Characteristics of global and regional drought, 1950-2000: Analysis of soil moisture data from off-line simulation of the terrestrial hydrologic cycle. J. Geophys. Res., 112, D17115, doi:10.1029/ 2006JD008288. 
— G. Goteti, and E. F. Wood, 2006: Development of a 50-yr highresolution global dataset of meteorological forcings for land surface modeling. J. Climate, 19, 3088-3111, doi:10.1175/JCLI3790.1.

Shi, X., J. Mao, P. E. Thornton, and M. Huang, 2013: Spatiotemporal patterns of evapotranspiration in response to multiple environmental factors simulated by the Community Land Model. Environ. Res. Lett., 8, 024012, doi:10.1088/ $1748-9326 / 8 / 2 / 024012$.

Spence, C., 2002: Streamflow variability (1965 to 1998) in five Northwest Territories and Nunavut rivers. Can. Water Resour. J., 27, 135-154, doi:10.4296/cwrj2702135.

St. Jacques, J.-M., and D. J. Sauchyn, 2009: Increasing winter baseflow and mean annual streamflow from possible permafrost thawing in the Northwest Territories, Canada. Geophys. Res. Lett., 36, L01401, doi:10.1029/2008GL035822.

Thornton, P. E., and N. E. Zimmermann, 2007: An improved canopy integration scheme for a land surface model with prognostic canopy structure. J. Climate, 20, 3902-3923, doi:10.1175/JCLI4222.1.

Twine, T. E., and Coauthors, 2000: Correcting eddy-covariance flux underestimates over a grassland. Agric. For. Meteor., 103, 279 300, doi:10.1016/S0168-1923(00)00123-4.

Viovy, N., 2011: CRUNCEP dataset. Accessed 1 August 2013. [Available online at http://dods.extra.cea.fr/store/p529viov/ cruncep/V4_1901_2012/.]

Walvoord, M. A., C. I. Voss, and T. P. Wellman, 2012: Influence of permafrost distribution on groundwater flow in the context of climate-driven permafrost thaw: Example from Yukon Flats basin, Alaska, United States. Water Resour. Res., 48, W07524, doi:10.1029/2011WR011595.

Wang, K., J. Mao, R. Dickinson, X. Shi, W. Post, Z. Zhu, and R. B. Myneni, 2013: Evaluation of CLM4 solar radiation partitioning scheme using remote sensing and site level FPAR datasets. Remote Sens., 5, 2857-2882, doi:10.3390/rs5062857.

Wang, S., 2005: Dynamics of land surface albedo for a boreal forest and its simulation. Ecol. Modell., 183, 477-494, doi:10.1016/ j.ecolmodel.2004.10.001.

- 2008: Simulation of evapotranspiration and its response to plant water and $\mathrm{CO}_{2}$ transfer dynamics. J. Hydrometeor., 9, 426-443, doi:10.1175/2007JHM918.1.

— face albedo of a temperate grassland. Agric. For. Meteor, 142, 133-142, doi:10.1016/j.agrformet.2006.03.027.

— , R. F. Grant, D. L. Verseghy, and T. A. Black, 2001: Modelling plant carbon and nitrogen dynamics of a boreal aspen forest in CLASS-The Canadian Land Surface Scheme. Ecol. Modell., 142, 135-154, doi:10.1016/S0304-3800(01)00284-8.

$\longrightarrow,-, \ldots$, and $\longrightarrow, 2002 \mathrm{a}$ : Modelling carbon-coupled energy and water dynamics of a boreal aspen forest in a general circulation model land surface scheme. Int. J. Climatol., 22, 1249-1265, doi:10.1002/joc.776.

,,--- , and,$- 2002 \mathrm{~b}$ : Modelling carbon dynamics of boreal forest ecosystems using the Canadian Land Surface Scheme. Climatic Change, 55, 451-477, doi:10.1023/A:1020780211008.

, A. P. Trishchenko, K. V. Khlopenkov, and A. Davidson, 2006: Comparison of International Panel on Climate Change
Fourth Assessment Report climate model simulations of surface albedo with satellite products over northern latitudes. J. Geophys. Res., 111, D21108, doi:10.1029/ 2005JD006728.

,-- , and X. Sun, 2007: Simulation of canopy radiation transfer and surface albedo in the EALCO model. Climate Dyn., 29, 615-632, doi:10.1007/s00382-007-0252-y.

—, Y. Yang, A. P. Trishchenko, A. G. Barr, T. A. Black, and H. McCaughey, 2009: Modelling the response of canopy stomatal conductance to humidity. J. Hydrometeor., 10, 521-532, doi:10.1175/2008JHM1050.1.

$\ldots, \ldots$, and A. Rivera, 2013: Spatial and seasonal variations in actual evapotranspiration over Canada's landmass. Hydrol. Earth Syst. Sci., 17, 3561-3575, doi:10.5194/hess-17-3561-2013.

_ J. Juang, J. Li, A. Rivera, D. W. McKenney, and J. Sheffield, 2014a: Assessment of water budget for sixteen large drainage basins in Canada. J. Hydrol., 512, 1-15, doi:10.1016/ j.jhydrol.2014.02.058.

_ D. W. McKenney, J. Shang, and J. Li, 2014b: A national-scale assessment of long-term water budget closures for Canada's watersheds. J. Geophys. Res. Atmos., 119, 8712-8725, doi:10.1002/ 2014JD021951.

_- J. Huang, D. Yang, G. Pavlic, and J. Li, 2015: Long-term water budget imbalances and error sources for cold region drainage basins. Hydrol. Processes, 29, 2125-2136, doi:10.1002/ hyp. 10343.

Widlowski, J.-L., and Coauthors, 2011: RAMI4PILPS: An intercomparison of formulations for the partitioning of solar radiation in land surface models. J. Geophys. Res., 116, G02019, doi:10.1029/2010JG001511.

WMO, 2008: Guide to meteorological instruments and methods of observation. 7th ed. World Meteorological Organization Rep. WMO 8, 680 pp. [Available online at www.wmo.int/pages/ prog/gcos/documents/gruanmanuals/CIMO/CIMO_Guide-7th_ Edition-2008.pdf.]

Wood, E. F., D. P. Lettenmaier, and V. G. Zartarian, 1992: A landsurface hydrology parameterization with subgrid variability for general circulation models. J. Geophys. Res., 97, 27172728, doi:10.1029/91JD01786.

Xiong, Y. J., and G. Y. Qiu, 2014: Simplifying the revised threetemperature model for remotely estimating regional evapotranspiration and its application to a semi-arid steppe. Int. J. Remote Sens., 35, 2003-2027, doi:10.1080/01431161.2014.885149.

Zaehle, S., and Coauthors, 2014: Evaluation of 11 terrestrial carbon-nitrogen cycle models against observations from two temperate Free-Air $\mathrm{CO}_{2}$ Enrichment Studies. New Phytol., 202, 803-822, doi:10.1111/nph.12697.

Zhang, H., S. Shen, X. Wen, X. Sun, and N. Mi, 2012: Flux footprint of carbon dioxide and vapor exchange over the terrestrial ecosystem: A review. Acta Ecol. Sin., 32, 7622-7633, doi:10.5846/ stxb201111051673.

Zhang, Y., S. Wang, A. G. Barr, and T. A. Black, 2008: Impact of snow cover on soil temperature and its simulation in the EALCO model. Cold Reg. Sci. Technol., 52, 355-370, doi:10.1016/ j.coldregions.2007.07.001. 